\title{
A figuração da mulher negra e a crítica do naturalismo em Machado de Assis: Arminda, Sabina e Mariana
}

Fecha de recepción: 1/6/2020.

Fecha de aceptación: 19/10/2020.

\section{Resumo}

Este artigo examina três textos curtos de Machado de Assis em que são figuradas mulheres negras (mestiças) ${ }^{1}$ escravizadas: o conto "Pai contra mãe" (Relíquias da Casa Velha, 1906); o poema narrativo "Sabina" (Americanas, 1875); e o conto “Mariana” (Jornal das Famílias, 1871). Tem a intenção de mostrar que, nesses contos, Machado subverte e desvenda o estereótipo social e literário das mulheres negras em geral e das "mulatas" em particular, bem como argumentar que essa subversão significa uma crítica ao naturalismo que caracteriza essas figuras estereotípicas e compõe a consciência fetichizada do homem branco proprietário.

\footnotetext{
1 Meu primeiro interesse pelo tema das mulheres negras e escravizadas em Machado de Assis foi despertado pela querida Elenice Neves Romualdo, que há dez anos tive o prazer de ter como aluna no curso de Especialização da Fundação Santo André, "Economia-Mundo, Arte e Sociedade". Junto com outros estudantes e ativistas do curso e do entorno, ela foi responsável por me introduzir à negritude, à questão racial; ela propôs o estudo dos contos de escravidão de Machado e com ela tive as primeiras conversas sobre o tema da mulher negra nesses textos. Durante alguns anos, o tema voltou aqui e ali, em geral em aulas, de modo disperso. Retornou com força na relação com outras alunas, as queridas camponesas e quilombolas a quem passei a lecionar quando entrei na UnB para dar aulas de literatura no curso de Licenciatura em Educação do Campo, há quatro anos. Foi nas conversas com elas, na preparação de aulas para elas, que o assunto se desenvolveu, as análises dos contos tomaram corpo, porque ali se mostrou, novamente, vivo e necessário. Esse artigo sintetiza o trabalho feito nos contextos de interlocução com essas mulheres. A elas agradeço e o dedico.
} 
The figuration of the black woman and the critique of naturalism in Machado de Assis: Arminda, Sabina and Mariana

\begin{abstract}
This article examines three texts by Machado de Assis featuring enslaved black (mixed-race) women: The short story "Father Against Mother" (Relics from an Old House, 1906); the narrative poem "Sabina" (Americanas, 1875); and the short story "Mariana" (Jornal das Famílias, 1871). It intends to show that, in these works, Machado subverts and unveils the social and literary stereotype of black women in general and mixed-race women in particular, as well as to claim that this subversion means a critique of naturalism that characterizes these stereotypical figures and makes up the fetishized conscience of the proprietary white man.
\end{abstract}

Keywords: Machado de Assis; Realism; Naturalism, Black Women; Slavery.

\title{
1. Machado de Assis e a crítica do naturalismo
}

No âmbito da compreensão de Machado de Assis como escritor realista, entendendo o realismo não como escola literária, nem como conjunto de procedimentos técnicos, mas sim como forma estética capaz de figurar as complexas forças motrizes da sociedade, um eixo de análise que se mostra frutífero é a sua crítica ao naturalismo e aos determinismos sociais e biológicos, que no século XIX despontavam com força.

A crítica do naturalismo remonta ao século XVIII europeu, ou seja, é anterior à emergência do naturalismo como escola literária na segunda metade do século XIX. Existia como momentos em obras artísticas e em teorias estéticas, e aparecia como procedimento criticado e superado no pensamento estético de diversos autores, entre os quais podemos destacar Goethe e $S_{c h i l l e r}{ }^{2}$, na ideia de que não é a finalidade da arte a reprodução mais fiel possível da natureza imediata, mas sim que a verdade da arte diz respeito à consistência interna da obra como mundo criado, em primeiro lugar, e a uma verdade social (ou espiritual, dependendo da teoria a que nos referimos) mais profunda do que aquela que se apresenta imediatamente na vida cotidiana. $O$ pensamento desses autores recebe, já muito posteriormente e contando com o desenvolvimento propriamente literário do naturalismo, uma síntese consistente e bastante definitiva na obra de György Lukács. A crítica do naturalismo perpassa toda a obra do pensador húngaro, tanto nas suas formas clássicas, que tem em Zola o representante mais importante, mas também no realismo socialista, nos romances de reportagem e outros criados a partir do século XX, que objetivam dar uma forma estética a uma tese ou teoria científica. 
Um ponto relevante nessa síntese lukácsiana que não aparece com força nos pensadores anteriores é que a tendência naturalista de criação literária, ao deterse na imediaticidade observável e torná-la em forma estética, acaba não apenas por manter-se no nível da superfície da realidade, mas, mais grave, por criar uma figura distorcida do que pretende retratar, justamente por representar quadros estáticos e não adentrar o movimento profundo das relações observáveis retratadas. Em “Narrar ou descrever?", Lukács apresenta um exemplo de Émile Zola em que esse tipo de distorção acontece. $\mathrm{O}$ alcoolismo do personagem de Germinal, Etienne Lantier, é atribuído sem mais à hereditariedade. As suas ações, que contradizem o seu caráter mais geral figurado no romance, ficam assim reputadas a um problema biológico hereditário, que, portanto, não pode ser superado pelas ações humanas individuais ou conjuntas e não se relacionam com o modo de vida efetivo deste e de outros personagens. Simplesmente, o personagem provoca explosões nas minas e catástrofes, numa atitude, novamente, que não tem relação com o seu caráter, e que se explica apenas pela sua embriaguez hereditária: "Em toda parte, a ação normal e homogênea do ambiente fica contraposta, sem nexo algum, às bruscas catástrofes determinadas pelo fator hereditário" (Lukács, 2006: 56).

Outro exemplo deste mesmo procedimento é a tese, subjacente à história de Madeleine Férat, da impregnação fisiológica: a filha da protagonista apresenta traços físicos do primeiro homem com quem a mãe se envolveu, muitos anos antes, e a quem a criança sequer conheceu. Nem é preciso se estender no absurdo dessa ideia, que tanto é falsa em termos científicos, como mostra uma concepção sexista e moralista do autor. Tudo se passa como se o ato sexual deixasse na mulher marcas biológicas, genéticas, do homem. Mas, além disso, nos dois casos, observamos que esses romances, ao menos nesses motivos expostos, promovem a ideia da naturalização dos comportamentos e a impossibilidade de autodeterminação humana, que decorrem do fato de não explorar os movimentos profundos, as forças motrizes do conjunto de relações humanas que figuram. Tampouco parece lidar com a casualidade de maneira verdadeira ou verossímil. Deter-se no real observável, na superfície imediata da realidade acaba por levar ao falseamento desta mesma realidade, precisamente por não construir literariamente os movimentos reais que a movem e explicam.

É interessante notar que, em Machado de Assis, esse mesmo motivo da semelhança física entre pessoas não aparentadas é trabalhado de uma maneira muito diversa em Dom Casmurro: ali, a semelhança do filho de Bento Santiago e Capitu com o amigo Escobar é o motivo externo que suscita a desconfiança de Bento de que a esposa o teria traído. Contudo, toda a cadeia de acontecimentos e ações, toda a profunda exploração do caráter do protagonista em suas relações mostra razões para seu o ciúme muito mais fortes e anteriores a essa suposta semelhança. Além disso, inclui-se no enredo a mania e o talento do pequeno em imitar as pessoas - e Escobar pertencia ao convívio cotidiano da família, sendo mesmo homenageado no nome dado ao menino, Ezequiel (primeiro nome de Escobar), assim como à filha deste deu-se o nome de Capitu; inclui-se também a semelhança, reconhecida por todos como verdadeira e casual, entre Capitu e a mãe 
de Sancha, sua amiga e posteriormente esposa de Escobar. Assim, no interior do enredo, a possível semelhança entre Ezequiel e Escobar pode ter duas outras explicações além daquela que Bento procura advogar em sua narrativa: ou bem uma casualidade, ou bem a convivência e a mania de imitar.

Além disso, e mais importante, toda a intenção de Bento de tratar essa semelhança como evidência da traição, e a própria ideia da traição, é longamente construída a partir da sua posição no mundo, sua condição de classe, suas relações familiares, seu caráter. Ao situar no caráter de Bento Santiago, na sua desconfiança e possessividade desenvolvidas ao longo de sua vida de proprietário e de filho único superprotegido de mãe rentista e viúva-perpétua, Machado opera literariamente uma crítica ao naturalismo, desvinculando da naturalidade, da determinação biológica, todo o desenrolar do enredo - que se centra nos caracteres e ações. Mas, essa crítica se mostra ainda mais forte no fato de que, ao desvendar o núcleo social ativo do caráter de Bento, desmascara o argumento naturalista em que a narrativa do protagonista se calca: a natureza dissimulada de Capitu, que exibe desde menina, e que constitui a sua tese - a tese do fruto escondido dentro da casca. No interior da narrativa, as ações e relações figuradas na obra, pela pena do próprio Bento Santiago, acabam por desmentir seu argumento naturalista.

Um expediente central da figuração crítica do naturalismo na obra de Machado é a construção dos seus narradores como não-confiáveis, conforme desenvolveu Roberto Schwarz. Diversos narradores de Machado, além de Bento Santiago, como o definitivo Brás Cubas, Matias Aires, aqueles dos contos que abordaremos, tanto em primeira como em terceira pessoa, constituem tipos proprietários não-confiáveis. Assim como Bento Santiago, outros erigem a trama de suas narrativas com base em princípios naturalistas, refletindo suas próprias noções deterministas e naturalizantes da história.

Compreender o caráter do narrador, em sua mais ampla determinação de classe e em seu traço individual mais específico - e a conexão entre esses planos - é a chave para compreender todo o significado da obra. Em suma, conhecer quem fala, quais seus interesses e concepções é o meio para compreender e fazer juízo de seu discurso. Mas um caráter não se distingue das suas ações.

Nas várias obras-primas de Machado vemos realizado esse fundamento positivo da crítica ao naturalismo desenvolvida por Lukács, a centralidade de ação. A verdade de uma obra artística se relaciona com a verdade da vida no sentido de que, para ambas, o núcleo verificador é a prática, a ação humana. Para o pensador húngaro, a verdade da vida - que é a um tempo a verdade do processo social e dos destinos individuais - "só se pode manifestar na práxis, no conjunto dos atos e ações dos homens" (Lukács, 2006: 57), de modo que considera centrais o papel objetivo da práxis e o seu caráter de prova da realidade: 
limitados, quando se traduzem na prática, isto é, quando os atos e as forças dos homens confirmam-nos ou desmentem-nos na prova da realidade. Só a práxis humana pode exprimir concretamente a essência do homem. O que é a força? O que é bom? Perguntas como essas obtêm respostas unicamente na práxis. (Lukács, 2006: 57 ys.)

Eis aqui um procedimento muito proveitoso para se examinar a tão repetida questão da traição de Capitu, apenas para ficar nesse precioso exemplo: são as palavras, sentimentos, a teoria de Bento confirmados ou recusados pelas ações, tanto a sua própria como a de Capitu, na relação deles com os demais personagens? A formulação da pergunta por vezes basta para se chegar à resposta.

Para além desta e de outras produções literárias, encontramos entre a concepção Lukács e de Machado de Assis relevantes aproximações estéticas, em especial na crítica teórica que este também dirige ao naturalismo. Enquanto Lukács vê em Zola um representante típico do naturalismo, Machado critica Eça de Queiroz, encontrando nele um discípulo de Zola e, assim como Lukács, estende essa crítica a toda escola literária chamada então de "realista". Um texto em que essa proximidade aparece é o célebre "Eça de Queirós: O Primo Basílio".

Em ambos os autores encontramos a ideia da inessencialidade do enredo da literatura naturalista, que não estabelece conexões entre o destino dos personagens e o destino social; a ausência de paixões e interesses verdadeiros dos personagens, que os torna em títeres a serem movimentados aleatoriamente pelos autores; uma função desmedida do acaso e, por fim, a permanência na imediaticidade dos fatos, que conduz a uma noção animalizante deles e à determinação natural das suas ações. Isso, por sua vez, impede que uma figuração da realidade social seja realmente conformada.

Destacamos aqui uma questão fundamental que aparece nos dois autores: a verdade das personagens, as ações consequentemente movidas pelo caráter e pelas relações reais constitui a verdade do retrato social. Em sua crítica a $O$ primo Basílio ${ }^{3}$, Machado aponta precisamente esse problema: a naturalização dos comportamentos humanos impede uma figuração verdadeira da realidade social que pretende retratar, quer dizer, o próprio quadro social, que é muitas vezes a intenção explícita da literatura naturalista, é falseado e comprometido pela naturalização das ações dos personagens. Machado traz o exemplo de Luiza. Segundo ele, a incongruência que existe entre seu caráter, mal construído (o autor não nos dá a sua "pessoa moral") e suas ações leva à conclusão de que o que a move é uma "vocação sensual”, que lhe seria natural. Se a intenção do autor era mostrar a frivolidade que grassa em sua classe, fruto da educação e da ociosidade desta classe, ela não foi realizada. Faltou, precisamente, a mediação entre as suas ações e o seu caráter:

Parece que o Sr. Eça de Queirós quis dar-nos na heroína um produto da educação frívola e da vida ociosa; não obstante, há aí traços que fazem supor, à primeira

3 As páginas deste texto, "Eça de Queirós: O primo Basílio", referem-se ao PDF da edição digital referida bibliografia (2008a). 
vista, uma vocação sensual. A razão disso é a fatalidade das obras do Sr. Eça de Queirós -ou, noutros termos, do seu realismo ${ }^{4}$ sem condescendência: é a sensação física. Os exemplos acumulam-se de página a página; apontá-los, seria reuni-los e agravar o que há neles desvendado e cru. Os que de boa fé supõem defender o livro, dizendo que podia ser expurgado de algumas cenas, para só ficar o pensamento moral ou social que o engendrou, esquecem ou não reparam que isso é justamente a medula da composição. Há episódios mais crus do que outros. Que importa eliminá-los? Não poderíamos eliminar o tom do livro. Ora, o tom é o espetáculo dos ardores, exigências e perversões físicas. (Machado de Assis, 2008a: 4)

Precisamente aquilo que o autor parece pretender retratar, as consequências humanamente empobrecedoras da educação frívola de uma classe, aparecem na obra como consequências de uma natureza da personagem: no interior do mundo criado da obra, suas ações são movidas não por aquela educação, mas por um impulso ou vocação natural - portanto dado e não socialmente criado - ao sensual. A forma conduz ao contrário do conteúdo proclamado. Podemos compreender essa inversão de conteúdo como aquela que é própria do fetichismo: toma como dado natural aquilo que deveria ser explicado; transforma o efeito em causa natural; oculta o núcleo social ativo que pretendia figurar.

Vale observar aqui que a crítica de Machado ao "espetáculo das exigências e perversões físicas" nada tem a ver com puritanismo ou moralismo. Nesse mesmo texto, ele retoma Aristófanes, Camões, Shakespeare, que escreveram termos crus, palavrões e atos sexuais. 0 problema não é a presença da exigência física, mas sim o seu descolamento do sentimento e das relações humanas, do seu núcleo social ativo, que acaba por torná-las naturalizadas e animalizadas. Na sequência da passagem citada acima, Machado escreve sobre a animalização de relações humanas na literatura naturalista:

Quando o fato the não parece bastante caracterizado com o termo próprio, o autor acrescenta-lhe outro impróprio. De uma carvoeira, à porta da loja, diz ele que apresentava uma "gravidez bestial". Bestial por quê? Naturalmente, porque o adjetivo avolume o substantivo e $o$ autor não vê ali o sinal da maternidade humana; vê um fenômeno animal, nada mais. (Machado de Assis, 2008a: 4)

É de se notar aqui o moralismo subjacente à animalização das relações físicas e biológicas do ser humano. Reduzir a gravidez ou o ato sexual à animalidade mostra o quanto o próprio autor não consegue reconciliá-los com núcleo propriamente humano que o ato sexual e a gestação e a maternidade encerram. Comentadores que viram na crítica de Machado tendências moralistas ou de conveniência social ${ }^{5}$ falharam em observar o quanto de moralismo se esconde sob essa forma animalizada de expressar e configurar atos e relações humanas.

4 Conforme a denominação da época, realismo significa o que nós chamamos hoje de naturalismo. Sempre que machado emprega este termo, está se referindo à escola naturalista. 
Mas a questão central aqui é o entrelaçamento entre realidade social, caráter e ações dos personagens. Apenas se os caracteres e ações se movem em consonância com o substrato social a que pertencem pode uma obra dar um retrato social verdadeiro. A ausência de vínculo entre as asserções e figuras da coletividade social e as ações e destinos dos personagens tornam a obra carente de verdade, tanto artística ${ }^{6}$ como social. Daniel Fonseca, em seu estudo sobre o tema, escreve:

\begin{abstract}
[...] a falha na construção de pessoas morais compromete o retrato social: qual o valor de ilustrações ou proposições gerais sobre a coletividade se as personagens não refletem as pressões advindas dessa coletividade em suas ações e relações? Com isso, naufraga o todo artístico, e são expressões da mesma fratura literária a inanição do indivíduo e a falência do retrato social. (Fonseca, 2014: 43)
\end{abstract}

Ora, vemos aqui uma proximidade significativa com a crítica lukácsiana, segundo a qual, no naturalismo, a objetividade social é morta, sem movimento porque desconectada da vida real dos personagens; e os personagens não são pessoas verdadeiras, mas estados de ânimo desconectados do mundo: "Sobre coisas inanimadas, fetichizadas, perpassa o hálito sem vida de um fugaz estado de ânimo" (Lukács, 2006: 69). O fundamento positivo dessa crítica se traduz na afirmação de que "A verdade do processo social é também a verdade dos destinos individuais" (ibíd.: 57). Na literatura realista observamos a configuração concreta das contradições fundamentais da sociedade em destinos humanos, o que Lukács, seguindo Engels, denomina o típico. 0 típico é a forma moderna do páthos antigo. Segundo o pensador húngaro, na épica clássica, o típico se alcançava no destino de um indivíduo que se fundia ao destino da sociedade como um todo: "Na filosofia antiga, 'páthos' significa a sublimação de uma experiência interior individual até o ponto em que ela se funda numa grande ideia, num heroísmo civil, na vida, enfim, do conjunto social" (Lukács, 1999: 96 y s.). Esse páthos ou tipicidade é o que Machado parece buscar, quando critica a separação de personagem e vida social e assume a exigência de criar os personagens como "pessoas morais", cujas ações e destino sejam coerentes e decorrentes de suas relações recíprocas no mundo social ao qual pertencem.

\title{
2. A subversão machadiana da figura naturalista da mulher negra
}

\subsection{O estereótipo de tipo naturalista}

Para além de sua crítica estética, e como indicamos brevemente acima, Machado criou verdadeiras obras-primas do realismo, condensações plásticas da unidade de destinos individuais e destino social, cristalizando na própria forma literária, sempre com o viés da ironia, a sua crítica ao naturalismo e à visão de mundo subjacente a ele, naturalizante e animalizante da vida humana. A partir dessas reflexões, pretendemos apresentar uma leitura de três personagens machadianas, mulheres mestiças escravizadas, a fim de argumentar que, com

6 Lívia Cotrim aponta (2018) que esse é um dos temas da estética de Goethe incorporados por Lukács. 
suas histórias, Machado não apenas subverte o estereótipo das mulheres nãobrancas em geral e negras e mestiças em particular, que predominou e predomina socialmente no Brasil e povoou a literatura brasileira, mas também que elas refletem uma crítica mordaz ao viés naturalista e fetichista que esse estereótipo contém, desvendando o seu núcleo humano ativo. Essa leitura segue a ideia de que as histórias e destinos dessas três mulheres constituem casos acabados e sublimes da desfetichização artística e, concomitantemente, da crítica práticoliterária do naturalismo.

Partimos do panorama da figuração das mulheres não-brancas e em particular mestiças na história da literatura brasileira, presente em "Mulheres marcadas: literatura, gênero, etnicidade”, de Eduardo de Assis Duarte. Ali, o autor apresenta casos da literatura brasileira, de Américo Vespúcio a Jorge Amado, passando por Gregório de Matos, José de Alencar, Aluísio Azevedo, em que as mulheres não brancas e muito especialmente as "mulatas" são figuradas conforme um estereótipo comum: mulher sensual, naturalmente sedutora, de "moral frouxa", portanto dada ao sexo, muitas vezes desterrada, sem família, relacionada ao material, ao terreno, à terra mesma e ao inferno. Sobre elas, não são poupados detalhes físicos, mas aparecem muitas vezes distanciadas do espiritual e sua subjetividade em geral não é complexa. Essa figura imaginária ilustra o terceiro termo do patriarcal ditado popular, "branca para casar, preta para trabalhar, mulata para fornicar".

Considero que esse ditado é desumanizador de todos os três tipos, quer dizer, significa uma mutilação da humanidade de todas, embora de formas e intensidades diversas. Para começar, essa é uma classificação masculina, em que o homem é o sujeito e a mulher é o objeto, cujo escopo de vida e atuação é por ele delimitado. E não apenas masculina, mas do homem branco. No caso da mulher branca, suprime-se a sua dimensão corpórea, sensível, como sujeito sexual; ela é um ser espiritual e moral, a "mãe virgem". A mulher mestiça é um ser sensível, carnal, sujeito-objeto sexual, caracterizada pela "moralidade frouxa" e por vezes contrastada ao espiritual. A mulher preta aparece num grau abaixo dessa escala, uma vez que não é sequer medida pela moralidade sexual: é para trabalhar, portanto naturalmente escrava, e a escravidão, como se sabe, implica a aproximação ao animal de trabalho. Podemos dizer que a "preta" é definida por uma moral diversa, ligada ao trabalho, à subserviência, em que a virtude se encontra em obedecer, não se rebelar e não ter vida própria.

O texto de Duarte, que busco seguir aqui, centra-se na figura que tem no sexo um traço definidor e que em geral é mestiça, embora possa aparecer também como negra, índia, morena - enfim, não-branca. Sobre ela, Duarte escreve: “[...] a mulata construída pela literatura brasileira tem sua configuração marcada pelo signo da mulier fornicaria da tradição europeia, ser noturno e carnal, avatar da meretriz." (Duarte, 2009: 6) Para concretizar, reproduzo aqui alguns dos vários casos apresentados por Duarte.

A referência histórica mais antiga que o autor traz é a carta de Américo Vespúcio, Mundus Novus, escrita em 1503, que testemunha a relação dos colonizadores 
com as mulheres nativas, indígenas, e que já mostra a idealização e a produção fantasiosa do homem colonizador sobre elas:

Nela, detém-se o piloto florentino em louvar a perfeição física de nossas índias, "bem feitas, sólidas, carnudas. Os seios duros, não se encontrando infelizes que os exibissem flácidos e pendentes. A pele dos ventres, unida e lisa, mesmo nas multíparas, que apresentavam corpos virginais. Esta semelhança entre umas e outras [...] se observa inclusive nas partes 'que não podem honestamente ser nomeadas" (Franco, 1976: 32).

E prossegue:

Ora, estas belas mulheres, tão belas que, como diria depois Pero Lopes de Souza, "nam ham nenhûa inveja às da rua nova de Lisbôa", se entregavam perdidamente a todos os excessos amorosos. Sua luxúria, diz Vespúcio, excede à imaginação humana. O homem possui quantas desejar, e elas inventam artifícios que tornem 0 ato amoroso mais excitante. Artifícios (aliás observados por outros viajantes) que são minuciosamente descritos. (Franco, 1976: 22, grifos nossos) (Duarte, 2009:7y s.)

Observa-se nessa passagem aqueles elementos que procuramos destacar: a sensualidade, a riqueza de detalhes corporais, a alegria masculina pela ausência da instituição monogâmica e da moral judaico-cristã. É interessante ressaltar que essa visão masculina se vincula à dupla moral sexual que vige até os dias de hoje: ao homem vale romper a monogamia no sentido sexual; um mesmo homem pode ser casado e respeitado e, ao mesmo tempo, ter relações com mulheres de "moral frouxa" ou prostitutas, já que o impulso sexual é reconhecido como natural e positivo nos homens; mas, às mulheres, é imposta uma rígida moral sexual, em que o seu desejo sexual é uma expressão de sua imoralidade. Como até os dias de hoje, o ato e o impulso sexual é virtude para os homens e vício para as mulheres.

Assim, para que os homens possam ser satisfeitos conforme a instituição monogâmica e a moral cristã e, ao mesmo tempo, conforme seu impulso sexual, as mulheres são divididas em duas categorias: a para casar e a para fornicar, a esposa e a prostituta; sem esquecer aquela para trabalhar, como vimos no infame ditado, que não entra nesse campo específico medido pela moralidade sexual, mas pertence à moralidade judaico-cristã em seu viés da virtude do trabalho. Ora, em contexto de colonização, essa categorização das mulheres pela moral sexual, que já existia na Europa do início do século XVI e que se aprofundaria na modernidade, adquire imediatamente definições raciais. Tanto pelo fato de que os povos originários da África e da América viviam sob outros sistemas sexuais, como porque, principalmente, eram os povos colonizados, portanto com menor humanidade e subordinados, desfrutáveis, no caso das mulheres, também em seus corpos. Na Europa, a situação de subordinação também fazia das mulheres camponesas corpos desfrutáveis para os senhores feudais (como o "direito à primeira noite" atesta) e, nos princípios do capitalismo industrial, são inúmeros os casos das operárias obrigadas a servir sexualmente seus patrões, em troca de não serem demitidas. Na constituição do Brasil como colônia fundada na 
escravidão de povos indígenas e principalmente africanos, atribui-se à mulier fornicaria, como sua determinação central, o traço racial. É significativo disso, na carta citada, que as indígenas sejam comparadas, precisamente, às prostitutas portuguesas.

O cinismo envolvido aqui é evidente: o homem branco, ao mesmo tempo que impõe a moral cristã para as mulheres, se regozija por haver um ambiente em que ela não governa, ou pode ser burlada: sejam os prostíbulos por ele alimentados, sejam os povos livres da moralidade cristã, mas dominados e subordinados nas colônias.

Avançando alguns séculos, a fim de apresentar os casos mais expressivos, reproduzimos o exemplo que Duarte traz de José de Alencar em O Guarani, a comparação entre Ceci e Isabel:

\begin{abstract}
Vendo aquela menina loura, tão graciosa e gentil, o pensamento elevava-se naturalmente ao céu, despia-se do invólucro material e lembrava-se dos anjinhos de Deus.
\end{abstract}

Admirando aquela moça morena, lânguida e voluptuosa, o espírito apegava-se à terra; esquecia o anjo pela mulher; em vez do paraíso, lembrava-se de algum retiro encantador, onde a vida fosse um breve sonho. (José de Alencar, apud Duarte, 2009: 8)

Aqui evidencia-se a categorização não em termos de monogamia e moralidade, mas em termos de elevação espiritual e terrenalidade. Observa-se a diferença de adjetivação, a branca é graciosa e gentil, a morena é lânguida e voluptuosa. Duarte afirma que a personagem morena, Isabel, carrega "a marca sensual da "mãe indígena”" e opera como uma síntese da mestiça brasileira. Esta reproduz, em contexto colonial, a divisão já existente no imaginário masculino europeu entre a loura do norte e a morena do sul mediterrâneo.

Cabe ainda um terceiro exemplo advindo de uma obra que pertence ao escopo do naturalismo:

\footnotetext{
O sensualismo desenfreado da mulata surge com toda força em $O$ cortiço, de Aluísio Azevedo, encarnado na figura de Rita Bahiana, "fruto dourado e acre dos sertões americanos". Aqui, a dupla adjetivação aponta para a natureza ambivalente da personagem, ao mesmo tempo sedutora e destrutiva. Eros e thanatos se associam em sua composição dramática, fazendo-a se destacar pelos "meneios" de uma "graça irresistível, simples, primitiva", que dão destaque à sexualidade animalesca pela qual o signo da serpente se inscreve na cadeia semântica da mulher. $O$ poder destrutivo da mulata "feita toda de pecado" acarreta o assassinato de Firmo, seu amante capoeirista, e a desagregação da família de Jerônimo, o imigrante cuja esposa torna-se alcoólatra e a filha, lésbica e prostituta (Duarte, 2009: 9).
}

Neste último caso em particular, mas em todos os demais apresentados por Duarte, chama a atenção a sedução irresistível que essas mulheres exerceriam 
sobre os homens. A força de sedução é depositada nas mulheres, como seu atributo. Portanto o impulso do homem em direção a ela vem dela, não dele; é só um reflexo da ação feminina sobre ele, lhe vem de fora. 0 homem é a vítima desse poder de sedução. Vemos aqui a inversão, o traço fetichizado desse tipo de figuração: assim como em Luiza, a "vocação sensual" da mulata é da sua natureza, especificamente, da sua natureza biológica: vem de sua descendência africana, indígena, vocação diretamente vinculada à sua pele "trigueira".

Sendo dessa natureza, essas mulheres estão confortáveis na sua posição se ser sensual. Sorriem molemente, satisfazem-se do efeito que causam e dos contatos sexuais. Não há conflito quanto a esse traço que, sabemos, é-lhes externo, pertence ao imaginário masculino. Nesse aspecto, Duarte destaca, já no século $\mathrm{XX}$, as figuras de Jorge Amado:

Eo modelo se repete em inúmeras personagens de narrativas do séculoXX. Basta lembrar as mulatas assanhadas de Jorge Amado, exaltadas, todavia, mais como sujeitos desejantes do que como objetos do desejo masculino. Destaco dentre elas, Gabriela, Tereza Batista, Tieta do Agreste. Poderia citar ainda, Glória, Ana Mercedes e tantas mais, dentre amantes lascivas, prostitutas ou mulheres em busca de realização amorosa e pessoal. De uma forma ou de outra, carregam consigo os traços do estereótipo. A afrodescendência marca sua constituição enquanto personagens, mas, também, seu caráter de figuras híbridas, nem brancas, nem negras. (Duarte, 2009: 10)

Novamente, vemos nessas criações que o desejo ou fantasia animalizado e animalizante dos homens é configurado como traço natural das mulheres. Ainda que não necessariamente as obras como um todo se construam sob um viés naturalista, a figuração das mestiças como portadoras de tais traços, como pessoas que detém essa natureza, opera com um viés naturalista, fixando-se numa superficialidade fetichizada da realidade e transpondo-a como um dado fixo para a natureza.

Da perspectiva do realismo, elas constituem um falseamento da realidade. Tal falseamento se torna muito evidente se observarmos uma característica marcante e chocante na figuração das mestiças, que é salientada por Duarte: por mais que façam sexo, essas mulheres jamais engravidam, nunca não são retratadas como mães. Por isso o subtítulo do texto de Duarte em que ele caracteriza e mostra a frequência desse estereótipo na literatura brasileira é denominado "erotismo e esterilidade" - são essas as duas características da mulata que povoa a imaginação masculina, "destinada ao prazer isento de compromisso":

7 Vale indicar que, na obra de Aluísio Azevedo, a par de Rita Bahiana, encontramos também uma outra mulher negra que subverte a figura da "preta para trabalhar", Bertoleza. Escrava fugida, quitandeira, junta dinheiro para comprar a sua liberdade; ela não pode fazer isso por conta própria, já que é fugida e portanto ilegal, e por isso pede ao sovina e inescrupuloso João Romão, seu "amante", que lhe compre a carta de alforria. Este compra uma carta falsificada e embolsa seu dinheiro. Passa a viver com ele, que no início considera seu "amigo", mas segue quase escrava, trabalhando à exaustão. É em grande parte por meio de seu trabalho que ele enriquece. Além de trabalhar de sol a sol, ela o serve sexualmente. Quando ele enriquece, pretende alcançar um nível social mais alto casando-se com a filha do vizinho, de baixa nobreza, e para isso precisa livrar-se de Bertoleza. Denuncia-a então aos seus donos, que a vem retomar. Ela, vendo que foi traída e recusando-se a voltar à escravidão, se suicida. 
Chama a atenção, em especial, o fato dessa representação, tão centrada no corpo de pele escura esculpido em cada detalhe para o prazer carnal, deixar visível em muitas de suas edições um sutil aleijão biológico: a infertilidade que, de modo sub-reptício, implica em abalar a própria ideia de afrodescendência (ibíd.: 6 y s.)

Nenhuma das personagens que Duarte retoma tem filhos; algumas se casam, mas ainda assim não engravidam. $O$ autor argumenta que a essa ausência subjaz a negação da afrodescendência, quer dizer, a ideia de que o povo brasileiro não descende de negras. Acrescenta a isso a ideia então presente inclusive em estudos pretensamente "científicos" - não esqueçamos que as teorias da eugenia aparecem como "ciência" no Brasil no mínimo desde o século XIX - de que as mestiças, como mistura de raças, seriam estéreis, assim como alguns animais que descendem de espécies distintas:

Como é sabido, os termos mulata e mulato derivam de mulo e mula, animais híbridos, frutos do cruzamento de cavalo e jumenta (ou égua e jumento), e, não nos esqueçamos, animais estéreis. Em adendo, é preciso lembrar que o discurso cientificista do século XIX, tendo à frente Arthur Gobineau, proclamava tal esterilidade também entre os relacionamentos interétnicos, alertando para os "frutos malsãos" das uniões entre brancos e negras. Assim, à doxa patriarcal junta-se o saber "científico", que transborda as fronteiras da medicina para chegar à literatura e ao discurso crítico de um Sílvio Romero, por exemplo, quando proclama que "as raças demasiado distanciadas pouco coabitam e, quando o fazem, ou não produzem ou, se produzem, são bastardos infecundos depois da segunda ou terceira geração" (Corrêa, 1996: 44).

Não deixa de espantar, todavia, que nos textos que estamos destacando, a ausência de procriação atinja inclusive a primeira geração, e até mesmo o sangue menstrual esteja ausente ou, quando presente, infenso à fertilidade. (Duarte, 2009: 12)

Chega a ser impressionante como essa suposta ciência, de cunho eugênico, pode ser capaz de simplesmente ignorar a evidência empírica e cotidiana mais imediata, que é o fato da gravidez e do nascimento de pessoas sãs. Bastardos sim, em diversos casos, inclusive pelo estupro sistemático: mas isso é uma relação social. Quando se diz malsãos se expressa um desejo e uma ideologia, naturalizante, de que os bastardos ou bem não nascessem ou, nascendo, não vingassem ou fossem biologicamente comprometidos. É também significativo que essa figura erótica e infértil seja tão frequente na literatura brasileira, em autores de diversas escolas, tendências e ideologias. Mostra como, pela franca consciência eugênica, ou por uma sensibilidade inconscientemente patriarcal e racista, essa personagem do imaginário masculino é reforçada e recriada ao longo de toda a modernidade e contemporaneidade brasileiras.

Essa figura, contudo, foi subvertida, como indicamos, por Machado de Assis em diversos momentos de sua obra. Na verdade, a mulata como mulier fornicaria não existe absolutamente em sua obra. Tampouco encontramos a "preta para trabalhar" naturalizada. Mas, para além de não reproduzir os estereótipos, Machado o subverte pela criação de figuras concretas, das quais selecionamos três: 
Arminda, do célebre conto "Pai contra mãe" (Relíquias da Casa Velha, 1906); Sabina, do poema narrativo "Sabina" (Americanas, 1875) e Mariana, do conto "Mariana" (publicado originalmente em Jornal das Famílias, 1871). Nestes, o estereótipo não apenas é revertido, como também essa reversão implica a desfetichização: em lugar de uma suposta natureza, agem a instituição da escravidão, os homens que a assumem e reproduzem na prática da vida, um conjunto de relações humanas que impedem essas personagens de ultrapassarem a posição (des)humana que lhes é imposta e que vai contra a sua natureza, sua sensibilidade, seus sentimentos, suas convicções, enfim, toda a sua subjetividade. Dessa maneira, Machado subverte também aquele procedimento naturalista, que vem muitas vezes calcado no falso cientificismo, determinista, positivista: o alcoolismo hereditário, a vocação sensual natural (em Luíza e nas várias mestiças brasileiras reduzidas ao estereótipo), a impregnação fisiológica, a perfídia inata (Capitu conforme a tese - desvendada - de Bento). Machado desvenda as forças sociais que reduzem o escopo de vida das personagens e lança luz ao seu profundo drama humano.

Essas figuras foram escolhidas por consistirem num contraponto quase direto ao estereótipo naturalista das mestiças: nenhuma delas aparece como sensual ou dada ao sexo sem envolvimento amoroso, em nenhum momento vislumbra-se nada do tipo de uma “vocação sensual”; duas delas serão mães (estão grávidas) e a maternidade é um sentimento profundo e determinante de suas ações e de seus destinos; duas delas sofrem por um amor verdadeiro e profundo e pensam em suicídio pela impossibilidade de realizar esse amor; uma delas o realiza e morre sem jamais ter feito sexo, a outra só não realiza por amor ao filho que carrega, tendo engravidado na única relação de amor que viveu. Vamos às nossas heroínas.

\subsection{Arminda}

Das três personagens que escolhemos abordar, Arminda, de "Pai contra mãe", é a menos desenvolvida em termos de construção da sua subjetividade e história pessoal. Na verdade, ela aparece como figura viva apenas ao final do conto. Ela não dá nome ao conto, como acontece com as outras duas, mas é a "mãe" do título. Diferentemente das outras duas, sua história não envolve uma relação amorosa, não gira em torno do amor, não é uma personagem apaixonada como são Sabina e Mariana. O que sabemos dela e de sua história pode ser sintetizado como se segue: Arminda é uma mulher mestiça escravizada na cidade do Rio de Janeiro, que está grávida e foge da escravidão, permanecendo escondida na cidade, e, alguns meses depois da fuga, é capturada e devolvida ao seu proprietário. A violência dessa captura e o seu pavor de retornar à escravidão a levam a abortar. Sua entrada no conto se dá no momento da captura, sendo referida antes como objeto de um anúncio de recompensa. Dos fatos de sua vida, anteriores e posteriores ao episódio da captura e do aborto, sabemos muito pouco: que fugira meses antes da captura e, por ela mesma, pela breve narração da sua súplica ao sujeito que a captura, sabemos que o seu dono é brutal, usa de violência física, de tal modo que grávida não conseguiria suportar. Nada mais. Na verdade, ela 
aparece como elemento da história de Cândido Neves, branco (livre) e pobre, que tem o ofício de pegar escravos fugidos, e é o "pai” do título. Toda a narrativa é centrada na história dele, e, no entanto, ela aparece no título com igual relevância e o sobrepuja na impressão que o conto causa a nós, leitores.

Podemos dizer que ela se constitui como uma verdadeira "pessoa moral", cujo páthos é retratado ao modo de uma pintura, que lança luz apenas a um momento de toda ação, mas a um momento que sintetiza passado e futuro, o significado do todo. Esse páthos, pretendemos mostrar, é justamente o amor de mãe, a maternidade, que constitui o motor de sua ação e a tragédia de seu destino: ela foge para livrar a si e seu filho da escravidão, e é impedida de ser mãe pela mesma instituição da escravidão. Embora o significado da vida de Arminda nos seja dado como por um único facho de luz, toda a construção da narrativa, a ação centrada em Cândido Neves, sua consciência, as demais personagens e o peculiar papel do narrador concorrem para determinar o significado da vida de Arminda.

O conto começa com uma espécie de prólogo do narrador em terceira pessoa, que está num momento posterior à abolição, acerca de instrumentos e práticas que deixaram de existir com o fim da escravidão: "A escravidão levou consigo ofícios e aparelhos, como terá sucedido a outras instituições sociais" (Machado de Assis, 2008b:2). O prólogo consiste numa apresentação de "alguns aparelhos" e de um ofício que fizeram parte da instituição da escravidão, e o narrador comenta que os aparelhos são mencionados apenas porque se vinculam a este ofício, o ofício de pegar escravos fugidos, que, saberemos, será assumido pelo protagonista Cândido Neves. O narrador refere três desses aparelhos: o ferro ao pescoço, o ferro ao pé e a máscara de folha de flandres. Descreve esta última:

\begin{abstract}
A máscara fazia perder o vício da embriaguez aos escravos, por lhes tapar a boca. Tinha só três buracos, dous para ver, um para respirar, e era fechada atrás da cabeça por um cadeado. Com o vício de beber. perdiam a tentação de furtar, porque geralmente era dos vinténs do senhor que eles tiravam com que matar a sede, e aí ficavam dous pecados extintos, e a sobriedade e a honestidade certas. Era grotesca tal máscara, mas a ordem social e humana nem sempre se alcança sem o grotesco, e alguma vez o cruel. (Machado de Assis, 2008b: 2)
\end{abstract}

Ao mesmo tempo em que considera que esse aparelho é grotesco, cruel e nos traz concretamente a sua dimensão de instrumento de tortura, pontua a sua efetividade na manutenção da "ordem social e humana", bem como seu papel na preservação de duas virtudes entre os escravos: a sobriedade e a honestidade. Ao indicar que a honestidade entre escravos é não roubar do proprietário, o narrador pressupõe a honestidade da própria escravidão, a "ordem humana”. 0 final da descrição, mostra um peculiar cinismo: "Os funileiros as tinham penduradas, à venda, na porta das lojas. Mas não cuidemos de máscaras.” (Machado de Assis, 2008b: 2, grifo meu) A passagem transmite um desdém do narrador pelo tema, como se se tratasse meramente de máscaras, e não de todo o conjunto de cruéis relações de violência que compõe a ordem escravista, e que este objeto condensa. 
A figuração da mulher negra e a...

Abordagem semelhante se verifica na sua descrição do ferro ao pescoço:

O ferro ao pescoço era aplicado aos escravos fujões. Imaginai uma coleira grossa, com a haste grossa também à direita ou à esquerda, até ao alto da cabeça e fechada atrás com chave. Pesava, naturalmente, mas era menos castigo que sinal. Escravo que fugia assim, onde quer que andasse, mostrava um reincidente, e com pouco era pegado (Machado de Assis, 2008b: 2).

O ferro ao pescoço aparece aqui como um objeto cuja finalidade é garantir a ordem, a propriedade. Assim como a máscara, é hediondo, mas serve a um bem. Quando diz que era "menos castigo que sinal", embora pesasse, nos faz pensar se uma pessoa que fosse efetivamente sujeita a tal aparelho diria o mesmo.

Na passagem para a narrativa propriamente dita, o narrador se volta à questão da fuga dos escravos, que já vinha preparada pela apresentação do ferro ao pescoço:

Há meio século, os escravos fugiam com frequência. Eram muitos, e nem todos gostavam da escravidão. Sucedia ocasionalmente apanharem pancada, e nem todos gostavam de apanhar pancada. Grande parte era apenas repreendida; havia alguém de casa que servia de padrinho, e o mesmo dono não era mau; além disso, o sentimento da propriedade moderava a ação, porque dinheiro também dói. (Machado de Assis, 2008b: 2, grifos meus)

O tom entre irônico e cínico do narrador aqui se evidencia nos termos grifados, que moderam, em alguma medida, a violência a que estavam submetidos os escravos, contrariando a própria apresentação dos aparelhos de tortura com que o conto se inicia. A afirmação de que "grande parte era apenas repreendida" porque se tratava de propriedade, que custou dinheiro, oculta uma verdade com outra: de fato, os escravos se caracterizam como propriedades, e com efeito, não era sempre interesse do proprietário matá-los ou mutilá-los a ponto de não servirem mais. Contudo, considerar que isso mitigava a sanha violenta dos proprietários é antes de tudo falso e, ademais, desconsidera a violência do próprio fato da escravidão. 0 modo engraçado, irônico, com que enuncia, "dinheiro também dói”, parece ser um elemento de sedução do leitor, como se falasse com liberdade e franqueza, sem comprometimento com este ou aquele interesse, sem receio de ofender, sem necessidade de ocultar. Mas toda sua forma de abordar explicita os horrores da escravidão ao mesmo tempo em que busca naturalizá-la, ao menos para o passado: tratava-se da "ordem humana".

Esse prólogo se conclui com a apresentação do ofício - a que se ligam os tais aparelhos - de pegar escravos fugidos. 0 narrador pontua que fugiam muito, às vezes ainda no próprio comércio, antes de serem vendidos - o que denota, contra a sua própria teoria, que não é preciso "apanhar pancada" para desejar fugir. Os proprietários lançavam anúncios em jornais oferecendo recompensas a quem prendesse e devolvesse o escravo fugido. Esses anúncios traziam nome, idade, traços físicos e objetos ou roupas que estivessem portando; às vezes ofereciam uma cifra determinada, às vezes apenas a promessa de bom pagamento. Além 
disso, "Muita vez o anúncio trazia em cima ou ao lado uma vinheta, figura de preto, descalço, correndo, vara ao ombro, e na ponta uma trouxa. Protestava-se com todo o rigor da lei contra quem o acoutasse" (Machado de Assis, 2008b:2-3). (Vale recordar que a uma pessoa escravizada era proibido usar sapatos...).

O narrador passa então aos sujeitos que se dispunham a assumir tal ofício:

Ora, pegar escravos fugidos era um ofício do tempo. Não seria nobre, mas por ser instrumento da força com que se mantêm a lei e a propriedade, trazia esta outra nobreza implícita das ações reivindicadoras. Ninguém se metia em tal ofício por desfastio ou estudo; a pobreza, a necessidade de uma achega, a inaptidão para outros trabalhos, o acaso, e alguma vez o gosto de servir também, ainda que por outra via, davam o impulso ao homem que se sentia bastante rijo para pôr ordem à desordem (ibíd.: 3).

Para o narrador, o ofício não é nobre em sua prática, isto é, não se pode dizer que seja elevado o ato mesmo de caçar, prender e arrastar de volta ao dono um escravo que fugira; entretanto, seguindo raciocínio análogo àqueles sobre máscara e ferro, seria nobre em sua finalidade: é um instrumento de manutenção da lei e da propriedade, um meio de pôr ordem à desordem, por isso carrega a elevação das "ações reivindicadoras".

Por suas asserções, podemos atribuir a esse narrador alguns traços: é um homem branco, condescendente com a instituição da escravidão ao menos para o passado, considerando-a como "ordem humana", conforme a lei e a garantia da propriedade; deve pertencer à classe proprietária ou assimilar-se ideologicamente a ela; é de se supor, por falar com tal naturalização de uma instituição que já teria sido superada em seu tempo, que comungue com o processo da abolição conservadora ${ }^{9}$. Parece tratar-se, portanto, de um tipo que se aproxima dos narradores desconfiáveis de Machado, muito bem caracterizados quando em primeira pessoa, mas cujos traços podem ser percebidos também em diversos narradores em terceira pessoa, pelos seus comentários, diálogos com o leitor, asserções sobre os personagens, suas ênfases e tons. Trata-se de um tipo de narrador cuja concepção e posição estão sob a mira crítica do autor, crítica que se constrói pela ação narrada.

No caso presente, contudo, o narrador não é o foco principal: difere em relevância para a narrativa daqueles em primeira pessoa, como Brás Cubas, Bento Santiago, Matias Aires e mesmo Coutinho, do conto “Mariana”, que protagonizam as histórias. Qual seria, então, o propósito de figurar esse narrador, com essa espécie de apresentação do contexto social por meio de objetos particularmente grotescos? Considero que ele serve a duas finalidades na narrativa: primeiramente, trazer à

90 processo pelo qual a classe proprietária foi indenizada pela libertação dos escravos, manteve a propriedade das terras e o poder de impor a permanência dos recém-libertos em situação análoga à escravidão, ou a sua marginalização nas cidades, por meio do não-assalariamento deles. Esse processo pode levar a incluir-se, no discurso dessa classe, palavras contrárias à escravidão, defensoras da liberdade; mas, como vemos nas asserções do narrador, não deixa de naturalizar a existência pregressa da escravidão (o que é consistente a intenção da classe de estendê-la na prática o mais possível). Sobre o processo da abolição conservadora e a posição da elite proprietária, ver, de Machado de Assis, a crônica de 19 de maio de 1888 da Gazeta de Notícias, Bons dias! (Pancrácio) e a crônica de 27 de setembro de 1887 da Gazeta de Holanda (Statu liber). 
luz o horror da escravidão, como instituição que tem na tortura um modus operandi, o meio principal de sua própria manutenção. A escravidão não sobrevive sem inspirar o terror do flagelo. A relevância disso para a narrativa é dar toda a dimensão daquilo de que os escravos fogem, particularmente, do que Arminda fugiu. Quando somos colocados na presença da Arminda grávida, já temos o espírito povoado desses horrores, sabemos precisamente do que ela pretende livrar a si e a seu filho ainda não-nascido.

Em segundo lugar, pelo viés do narrador, que expõe com clareza, mas naturaliza a escravidão como uma ordem humana e justifica a tortura como meio de manter tal ordem, somos preparados para compreender a consciência de Cândido Neves não como exceção, mas sim como um modo da consciência dominante. Sigamos a história deste, para então voltarmos a esse tema.

Como indicamos, Cândido Neves é um homem branco, livre, pobre, sem estudos; de sua personalidade, a primeira característica que nos é apresentada é chamada pelo protagonista e pelo narrador de caiporismo:

Cândido Neves - em família, Candinho -, é a pessoa a quem se liga a história de uma fuga, cedeu à pobreza, quando adquiriu o ofício de pegar escravos fugidos. Tinha um defeito grave esse homem, não aguentava emprego nem ofício, carecia de estabilidade; é o que ele chamava caiporismo (ibíd.: 3).

Caiporismo significa azar, má-sorte, ou seja, dar-se mal por motivos casuais, ou mesmo feitiços que possam ser lançados contra a pessoa, em suma, motivos externos à própria ação. Entretanto, a narração contesta essa ideia, contando as várias profissões que procurou abraçar, e das quais desistiu rapidamente por moto próprio, alegando a si mesmo diversas razões. 0 narrador oferece duas: a primeira, tipógrafo, demorava a aprender e pagava mal, ser caixeiro num armarinho lhe feria o orgulho pela obrigação de atender e servir. As demais são apenas mencionadas: "fiel de cartório, contínuo de uma repartição anexa ao Ministério do Império, carteiro e outros empregos foram deixados pouco depois de obtidos" (ibíd.: 3). Claramente, Cândido não se dava à atenção detida por longo tempo, a estar parado, atender, servir, a obrigação constante, a monotonia desses empregos. Não se trata aqui de moralizar o personagem por sua antipatia ao trabalho assalariado; ninguém seria obrigado a gostar. Trata-se de observar sobre isso duas coisas: primeiro, que ele atribui seu insucesso a algo fora de si, ao caiporismo; segundo, que, diante de sua pobreza, a todas essas profissões ele preferiu a de "pegar escravos fugidos":

Cândido Neves perdera já o ofício de entalhador, como abrira mão de outros muitos, melhores ou piores. Pegar escravos fugidos trouxe-lhe um encanto novo. Não obrigava a estar longas horas sentado. Só exigia força, olho vivo, paciência, coragem e um pedaço de corda. Cândido Neves lia os anúncios, copiava-os, metia-os no bolso e saía às pesquisas. Tinha boa memória. Fixados os sinais e os costumes de um escravo fugido, gastava pouco tempo em achá-lo, segurá-lo, amarrá-lo e levá-lo. A força era muita, a agilidade também (ibíd.: 5, grifo meu). 
Esse ofício era conforme as qualidades de Cândido Neves, forte, ágil, com boa memória e de "olho vivo", e lhe trouxe um "encanto novo". Observamos, desde já, que não há contradição em seu espírito, não há luta interna quanto a assumir esse ofício. Trata-se, afinal, de um ofício socialmente aceito e até bem-visto, como atesta o discurso do narrador no prólogo. Além disso, quando da captura de Arminda, o narrador comenta que "Quem passava ou estava à porta de uma loja, compreendia o que era e naturalmente não acudia” (ibíd.: 8, grifo meu).

Cândido Neves, tendo adotado essa ocupação, apaixona-se e se casa com Clara, uma moça pobre e órfã que vivia com sua Tia Mônica e com ela costurava para fora. Casados, passaram a viver os três juntos. A situação era de uma pobreza remediada, os ganhos não eram regulares, mas quando vinham eram bons e compensavam o período que passava sem ganhar.

A alegria era comum aos três. O casal ria a propósito de tudo. Os mesmos nomes eram objeto de trocados, Clara, Neves, Cândido; não davam que comer, mas davam que rir, e o riso digeria-se sem esforço (ibíd.: 4).

Ambos queriam um filho, mesmo sabendo das dificuldades da vida, e contra os conselhos da Tia. Depois de algum tempo em que o filho "não sabendo daquele desejo específico, deixava-se estar escondido na eternidade", Clara engravida, para grande felicidade do casal.

Não houve mais que espreitar a aurora do dia grande. A esposa trabalhava agora com mais vontade, e assim era preciso, uma vez que, além das costuras pagas, tinha de ir fazendo com retalhos o enxoval da criança. À força de pensar nela, vivia já com ela, media-lhe fraldas, cosia-lhe camisas (ibíd.: 4).

Machado constrói nessas e em outras passagens do conto a felicidade que trazem os sentimentos de maternidade e paternidade. Mesmo com toda a dificuldade que passavam, não abriam mão do filho, que significava uma grande realização.

O conflito começa a ganhar corpo quando os ganhos de Cândido Neves começam a diminuir devido ao aumento da concorrência no interior desse ofício, que o narrador atribui ao desemprego. A pobreza faz com que emerja na casa, pela voz da Tia Mônica, a ideia de darem o filho para a Roda dos Enjeitados. Levado pelo desespero, Cândido revisa anúncios velhos e se lança em tentativas frustradas, como quando capturou um "preto livre" e tomou uma surra dos seus parentes.

Contudo, chegam à situação em que são despejados da casa pobre em que moravam. Tia Mônica consegue para os três um quarto de favor na casa de uma senhora rica e dois dias depois o filho nasce. Diante da situação extrema, ela convence o casal a entregá-lo à Roda. E aqui tomamos o primeiro contato com nossa heroína: 
Uma, porém, subia a cem mil-réis. Tratava-se de uma mulata; vinham indicações de gesto e de vestido. Cândido Neves andara a esquisa-la sem melhor fortuna, e abrira mão do negócio; imaginou que algum amante da escrava a houvesse recolhido. Agora, porém, a vista nova da quantia e a necessidade dela animaram Cândido Neves a fazer um grande esforço derradeiro. Saiu de manhã a ver e indagar pela Rua e Largo da Carioca, Rua do Parto e da Ajuda, onde ela parecia andar, segundo o anúncio. Não a achou; apenas um farmacêutico da Rua da Ajuda se lembrava de ter vendido uma onça de qualquer droga, três dias antes, à pessoa que tinha os sinais indicados. Cândido Neves parecia falar como dono da escrava, e agradeceu cortesmente a notícia. Não foi mais feliz com outros fugidos de gratificação incerta ou barata (ibíd.: 7).

Chama a atenção que a recompensa pela sua captura seja alta. É de notar também que Cândido atribua a dificuldade de encontrá-la a ter sido recolhida por algum amante, bem como o seu comportamento de dono. Sem sucesso, na noite seguinte, Cândido sai com seu filho em direção à Roda, abraçando-o, beijando-o e pretendendo demorar-se ao máximo, tal era o seu conflito interior. Nesse caminho, que procura encompridar entrando por ruas paralelas, dá-se seu encontro e o nosso com Arminda. Ao vê-la, sentiu uma grande comoção, pediu ao farmacêutico que guardasse o filho e foi atrás dela.

- Arminda! bradou, conforme a nomeava o anúncio.

Arminda voltou-se sem cuidar malícia. Foi só quando ele, tendo tirado o pedaço de corda da algibeira, pegou dos braços da escrava, que ela compreendeu e quis fugir. Era já impossível. Cândido Neves, com as mãos robustas, atava-lhe os pulsos e dizia que andasse. A escrava quis gritar, parece que chegou a soltar alguma voz mais alta que de costume, mas entendeu logo que ninguém viria libertá-la, ao contrário. Pediu então que a soltasse pelo amor de Deus.

- Estou grávida, meu senhor! exclamou. Se Vossa Senhoria tem algum filho, peço-lhe por amor dele que me solte; eu serei tua escrava, vou servi-lo pelo tempo que quiser. Me solte, meu senhor moço! - Siga! repetiu Cândido Neves. - Me solte! - Não quero demoras; siga!

Houve aqui luta, porque a escrava, gemendo, arrastava-se a si e ao filho. [...] Arminda ia alegando que o senhor era muito mau, e provavelmente a castigaria com açoutes, - cousa que, no estado em que ela estava, seria pior de sentir. Com certeza, ele the mandaria dar açoutes.

- Você é que tem culpa. Quem lhe manda fazer filhos e fugir depois? perguntou Cândido Neves (ibíd.: 7 y s., grifos meus)

Nota-se o apelo de Arminda à condição paterna de Cândido Neves. Arminda não tem nenhuma ciência do drama de Cândido, que estamos seguindo, e este não lhe responde; mas esse apelo indica a condição que está dada a nós, leitores: ambos vivem um mesmo drama; ambos querem salvar o próprio filho, Cândido, da Roda e da miséria; Arminda, da escravidão.

Seguimos detalhadamente a pobreza e a perspectiva de entregar o filho, vividas por Cândido; mesmo que não simpatizemos com suas escolhas ou com aspectos do seu caráter, há uma construção pela qual sua finalidade é justificada, legítima. 
O sentimento da paternidade, de um direito natural de criar o próprio filho, conviver e viver com ele, é um fundamento da legitimidade de seu objetivo.

Já os açoites e maldades do dono de Arminda, não conhecemos diretamente. Nesse contexto é que considero muito significativo o papel do prólogo: dá-nos a conhecer aquela peculiaridade da instituição da escravidão, a tortura. Cândido a culpa pela situação em que se encontra, arrastada grávida pelas ruas como um animal, e pelos açoites que "com certeza, ele lhe mandaria dar" - diz o narrador, em discurso indireto livre, sem comentar. Mas nós sabemos do que ela foge. As suas súplicas, reiterando os açoites, a condição de gestante que não impediria ou suavizaria nada, a maldade do dono, se somam à nossa imaginação povoada de máscaras e ferros. Mais ainda, sabemos do que ela quer livrar o filho. Alguém culparia uma pessoa que agisse, seja lá como for, para salvar o filho da tortura? Não a julgamos como Cândido, porque justificamos a sua fuga. Assim, para nós, leitores, a finalidade de Arminda compete com a de Cândido em teor e legitimidade. No interior do conflito, em que um dos lados vai perder o filho, os dois parecem se justificar. Essa igualdade entre eles se expressa também no título, "pai contra mãe".

Contudo, na sociedade escravista, evidentemente, não existe igual legitimidade. Isso fica claro, novamente, pela afirmação do narrador de que Arminda percebeu que ninguém a viria salvar. Ao contrário. Machado lança luz para a igual legitimidade, a partir do núcleo humano dos sentimentos de paternidade e maternidade, e também para o fato de que a ordem social escravista prevalece na vida, na lei seguida por todos os que lhe recusam socorro e na consciência naturalizante do narrador e de Cândido Neves. Nesta ordem social, o conflito só pode ter um vencedor, e esse vencedor só pode ser o elo mais forte, neste caso - simbolicamente - o "pai”, branco livre e pobre. É claro que Arminda é arrastada e devolvida ao dono, que paga a recompensa a Cândido:

\begin{abstract}
Arminda caiu no corredor. Ali mesmo o senhor da escrava abriu a carteira e tirou os cem mil-réis de gratificação. Cândido Neves guardou as duas notas de cinqüenta mil-réis, enquanto o senhor novamente dizia à escrava que entrasse. No chão, onde jazia, levada do medo e da dor, e após algum tempo de luta a escrava abortou.
\end{abstract}

O fruto de algum tempo entrou sem vida neste mundo, entre os gemidos da mãe e os gestos de desespero do dono (ibíd.: 8).

No campo do simbólico, diversos são os elementos que se poderiam aventar. A hierarquia patriarcal expressa na vitória do "pai”; a brincadeira com os nomes, Cândido, Neves, Clara, que denotam o branco; a oposição entre a classe dos homens livres e pobres e a classe escravizada. Contudo, considero mais profícuo perseguir a ideia de Arminda como núcleo humano capaz de desvendar todas as demais relações que compõem a sociedade escravista em seu caráter grotesco, e tendo como motor ou páthos desse núcleo humano a maternidade. É estar grávida, ser mãe, no interior da construção narrativa do drama de Cândido que traz à luz a sua humanidade. A condição de escrava 
é um obstáculo à realização da maternidade, uma relação que demanda a condição de sujeito. Na disputa do pai contra a mãe, aquele segue pai, esta termina não-mãe.

Não se trata de eternizar a maternidade como condição de humanidade da mulher. Esta relação está em foco nesse conto, como poderiam estar outras; ela é uma das formas de relação que, historicamente, são negadas pela condição de escravidão. $O$ interessante é que Machado elege aqui este vínculo humano para trazer à tona, por um lado, toda a inumanidade da escravidão e das figuras, proprietárias ou não, que a impõem; e, por outro, toda a humanidade da figura de Arminda. Assim, eleva a própria gravidez, e com isso a maternidade, ao seu patamar humano - afastando-se cabalmente de toda ideia animalizante, como denuncia na passagem de Eça de Queiroz sobre a "gravidez bestial". Além disso, é importante observar também que não aparecem no conto relações amorosas ou sexuais envolvendo Arminda. A meu ver, isso significa que ela não está aqui representada como alguém que os proprietários tomam por objeto sexual, como no estereótipo da "mulata"; parece bem mais ser tomada pelo proprietário como a "preta para trabalhar" (o que não significa, sabemos, que não possa ser explorada também sexualmente). Ora, ela se nega à subserviência e exige sua vida própria: exige ser mãe. 0 destino de Arminda carrega um elemento trágico, porque toda a sua condição de vida nega a sua natureza própria, humana. Vemos figurado um contraponto vivo e concreto - afirmativo da afrodescendência do povo brasileiro, mas muito mais do que isso - aos estereótipos de tipo naturalista que marcaram e ainda marcam as mulheres negras.

Já Cândido, seu antípoda, mostra sua desumanidade na ausência de conflito interno, de toda disputa em seus sentimentos - o que é preparado na narrativa, a começar pela opção do ofício. Embora tenha assistido a "todo esse espetáculo", sua cabeça estava no filho que deixara com o farmacêutico. Em posse do dinheiro, ele voltou à farmácia, tomou o filho e levou-o de volta para casa, onde Tia Mônica o aceitou, já que trazia também o dinheiro e, tal como ele, condenou Arminda por fugir e abortar.

Cândido Neves, beijando o filho, entre lágrimas, verdadeiras, abençoava a fuga e não se lhe dava do aborto.

- Nem todas as crianças vingam, bateu-lhe o coração (ibíd.: 9).

O desfecho magistral do conto parece retomar a "ordem social e humana" do narrador na apresentação inicial, em que escravos fogem, sujeitos pobres e caiporas os pegam por recompensa e lojas exibem máscaras e ferros nas suas portas; uma ordem em que "nem todas as crianças vingam". Cândido não pensou nessas palavras, sua atenção estava toda no filho, "não se lhe dava do aborto". Essas palavras não foram pensadas, e sim batidas pelo seu coração. Sente-se legitimado, recompensado e realizado. Tudo está bem e conforme à ordem. Como Lukács nos mostra, nas obras de arte o desfecho lança luz a todo o enredo, conferindo-lhe significado. Aqui, terminamos com o sentimento de Cândido de legitimação e naturalização de um ato que contradiz o seu sentimento mais profundo, o amor parental. 
Pelo que ficou dito, observamos que o prólogo não é um "pano de fundo" social, sobre o qual passeiam personagens como estados de ânimo. Ali estão contidos elementos sociais concretos que movem a vida e o destino dos personagens, bem como elementos da naturalização da escravidão na consciência do narrador, que o coração de Cândido espelha. Na forma do conto, vemos Machado subverter aquela prática naturalista, e, nesse sentido, parece significativo que ele descreva certos objetos, parodiando um naturalismo das coisas, mas dando-lhes um conteúdo vivo pelo correr da trama.

Mas a subversão do viés naturalista, está, em síntese, na figuração que despe tanto a gravidez quanto a mulher negra da animalidade que o viés do proprietário branco e sua ordem própria lhes confere. Desnuda seu sentido humano. Não é a mulher negra que naturalmente é não-mãe; éa escravidão que lhe rouba esse atributo, e com ele a sua humanidade. Com isso, explicita o nível de desumanização que se imprime no caráter dessa classe e de seus parasitas no processo de impor a sua dominação. Invertendo o agente da desumanização, desfaz e desvenda a fetichização da mulher negra.

\subsection{Sabina}

Diferentemente de Arminda, as histórias de Sabina e Mariana centram-se em relações de amor, são personagens apaixonadas. As duas se apaixonam pelos filhos das casas proprietárias, aquela na fazenda, esta na cidade do Rio de Janeiro, mas encontram desenvolvimentos e destinos diversos. Mariana se suicida pela impossibilidade de realizar o seu amor; Sabina realiza o seu amor por um momento, mas seu amante se casa com outra mulher de sua classe, e ela, grávida, desiste do projeto de suicídio por amor ao filho. 0 ponto central dos dois textos é a figuração humana das duas mulheres escravas, a sua grandeza de caráter e sua subjetividade que ultrapassa o estreito escopo de suas condições objetivas. Aqui, a questão do narrador é fulcral. Enquanto em "Mariana" o narrador em primeira pessoa busca naturalizar a condição da escravidão e se esquiva de afirmar francamente o verdadeiro caráter humano de Mariana, o eu-lírico da poesia se aproxima de Sabina, e joga sobre ela uma luz humana e amorosa, conhecendo seus conflitos interiores. Uma vez que as duas são mestiças belas e amorosamente envolvidas, essas histórias constituem um contraponto direto à "mulata” fornicaria, do infame estereótipo.

Entre as mulheres escravizadas, um traço particulariza e une as nossas duas heroínas: são "crias da casa”. Em verdade, essa é a condição objetiva - e subjetiva - que fundamenta seus sentimentos, suas ações e seus destinos. É uma condição que carrega um certo privilégio em comparação com as demais pessoas escravizadas, mas que, como Machado explora nas duas histórias, carrega também uma peculiar crueldade. $O$ caráter perverso dessa relação é que ela proporciona uma experiência e uma proximidade com a vida livre, com a propriedade de si mesma, com o acesso a coisas, conversas, sentimentos, temas que são próprios da liberdade; mas, nas situações definidoras da vida, toda essa experiência é negada pela condição imperante da escravidão. A esperança que essa particularidade lhes traz é provada imaginária. Ao fim e ao cabo, no que verdadeiramente importa, elas 
são escravas tanto quanto quaisquer outras que vivem na senzala: não possuem a si mesmas, a sua dignidade humana não tem efeito social. A decepção que essa percepção lhes causa é tal que as conduz a destinos trágicos.

Tratemos primeiramente de Sabina. Sua história é cantada pelo poeta, que se aproxima e nos aproxima dela, sente as suas paixões e tormentos. Como procuraremos indicar, a partir dos comentários líricos que interpõe à narrativa, não se trata aqui de um sujeito cínico, como o narrador de "Pai contra mãe" ou, veremos, o Coutinho de "Mariana”. É um eu-lírico que, se mostra uma adesão a um padrão de beleza branco, ao comparar Sabina banhando-se com uma Mãe D'água loira de olhos azuis oriunda do folclore europeu e ao modelo clássico - embora a compare também com a morena Sulamita, a esposa de Salomão em nenhum momento a julga moralmente, ou lhe tira a legitimidade de seu sentimento e de seu sonho, e sofre com ela e conosco o seu destino trágico. Ele a apresenta:

Sabina era mucama da fazenda; Vinte anos tinha; e na província toda Não havia mestiça mais à moda, Com suas roupas de cambraia e renda.

Cativa, não entrava na senzala, Nem tinha mãos para trabalho rude; Desbrochava-lhe a sua juventude Entre carinhos e afeições de sala.

Era cria da casa. A sinhá-moça, Que com ela brincou sendo menina, Sobre todas amava esta Sabina,

Com esse ingênuo e puro amor da roça (Machado de Assis, 2009: 206).

Caracteriza aqui a condição diversa das demais pessoas escravizadas na fazenda onde Sabina vivia: ela é "mucama”, "cria da casa”. Cresceu na casa grande com a família proprietária, de modo que teve acesso a coisas que as demais escravizadas não têm, como as roupas finas, o cuidado consigo mesma. Não é obrigada a se engajar em trabalhos pesados, nem a viver na senzala. 0 poeta destaca a amizade com a "sinhá-moça”, a filha da família proprietária brincou com Sabina na infância e lhe tinha especial carinho, a amava "sobre todas as outras". Ora, que outras? Certamente, as outras mucamas ou escravas. O poeta assim evidencia a distância real que havia entre elas e o tipo de afeição de que se trata: verdadeira, mas ao ponto em que se pode amar a uma escrava. Também é de se supor que a proximidade com as pessoas da família proprietária e a afeição relativa que esses lhe dedicam seja recíproca, quer dizer, que também Sabina desenvolva sentimentos por tais pessoas. Isso porque, como cria da casa, não conhece outra família. Não tem outras relações e laços familiares como poderia ocorrer às demais pessoas escravizadas. Mas, o amor de Sabina pode ser inteiro, sem ressalvas, de um modo que o suposto amor dos proprietários pela escrava não poderia ser. 
O poeta então situa as possibilidades de relação que Sabina tinha, e o seu amor pelo filho da família:

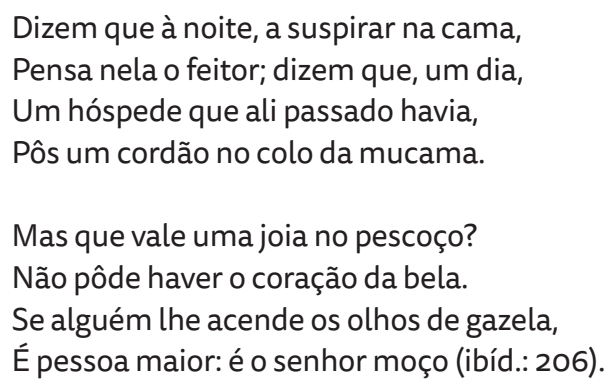

Sabina poderia amar o feitor ou o hóspede, que lhe seriam compatíveis, seriam amores possíveis, e seriam mais do que poderiam esperar as demais escravas. Mas ela ama "pessoa maior", o próprio filho do proprietário.

O poeta trata então dele, Otávio, que tem vinte anos como Sabina, estuda Direito na Academia, está no terceiro ano da faculdade, tem perspectiva de se formar bacharel e fazer-se legislador do Estado. Estudioso e dedicado, espera as férias passadas na fazenda do pai, entre passeios, cavalgadas, caças e conversas filosóficas com o vigário da região, para orgulho de seu pai. Quanto aos modos e aspectos, o poeta o caracteriza como se segue:

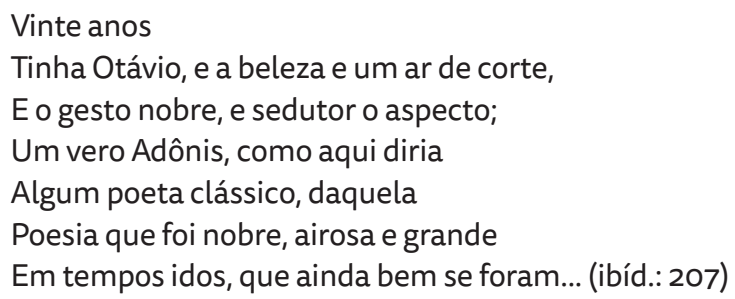

Belo, de gesto nobre e aspecto sedutor, "um vero Adonis", nas palavras de “algum poeta clássico". Razões não faltam para a jovem e ingênua Sabina apaixonar-se por ele. Porque deveriam seus sentidos e sentimentos finos, apurados, delicados restringirem-se? Por que não teria ela o direito de encontrar para si o objeto do seu amor? Ora, ela tem e exerce tal direito, mas não é tão ingênua a ponto de, por si mesma, agir em direção à sua realização. Ela ama silenciosamente.

Vale aqui um parêntese sobre os versos finais da passagem citada, em que o eulírico refere a poesia "nobre, airosa e grande" de um passado clássico que "ainda bem" se foi. Por mais bela e grandiosa que tenha sido a poesia desse tempo, é bom que esse tempo tenha passado. Imagino aqui algo como a atração e a repulsa concomitantes que sentia Heine com relação à Grécia antiga. Por mais maravilhosa que tenha sido a sua arte, incomparável até, os gregos eram, para o poeta alemão, também cruéis, injustos, odiosos. Será que o eu-lírico não refere esse passado talvez indicando seu próprio tempo, em que histórias trágicas como a de Sabina, que pode ser cantada de maneira a encher nossos ouvidos e imaginação, tenham também de passar, devam passar? Talvez indique que 
A figuração da mulher negra e a...

superar matéria de tão bela poesia seja necessário e bom; superar as relações de escravidão significa o fim desse tipo de tragédia e beleza: melhor assim.

O sentimento de Sabina por Otávio é legítimo e profundo, mas não a conduz à ação. É ele quem a vê, a deseja e seduz. Antes de entrar no ponto central, a sua sedução, vale reproduzir aqui o quadro que o poeta desenha diante de Otávio. Este passeava de manhã, de arma ao ombro para talvez caçar, de espírito leve e solto, e ladeava o rio:

Pela aberta da folhagem, Que inda não doura o sol, uma figura Deliciosa, um busto sobre as ondas Suspende o caçador. Mãe d'água fora, Talvez, se a cor de seus quebrados olhos Imitasse a do céu; se a tez morena, Morena como a esposa dos Cantares, Alva tivesse; e raios de ouro fossem Os cabelos da cor da noite escura, Que ali soltos e úmidos the caem, Como um véu sobre o colo. Trigueirinha, Cabelo negro, os largos olhos brandos Cor de jabuticaba, quem seria, Quem, senão a mucama da fazenda, Sabina, enfim? [...]

E ora toda se esconde, ora ergue o busto, Talhado pela mão da natureza

Sobre o modelo clássico (ibíd.: 208).

Aí vai o retrato de Sabina a se banhar: bela como o modelo clássico, a recordar uma Mãe D’água europeia, se essa tivesse as cores de Sulamita. É de supor que, sendo mestiça, tem os olhos, cabelos e pele negras, e as formas e traços "clássicos", puxados da ascendência branca. Toda uma discussão caberia aqui sobre as formas e traços do padrão de beleza branco, que as mestiças trazem em maior ou menor medida. Mas, o certo é que Sabina se aproxima desse modelo ao mesmo tempo em que exibe sua ascendência negra, que, por sua vez, se liga no imaginário masculino branco à sensualidade e à possibilidade de desfrute sexual sem as rédeas do casamento ou da moralidade.

Isso está subjacente e naturalizado nas palavras que Otávio escolhe a dedo para seduzi-la, e que, para além disso, esconde uma perversidade sob sua aparente delicadeza de sentimentos e ingenuidade. Antes de reproduzir a sua fala, vejamos como o poeta figura os sentimentos dos dois no momento do encontro, e o comentário que insere na narrativa. Otávio vê Sabina se banhando, a reconhece e sua reação subjetiva é o desejo sexual: "Logo a conhece Otávio, / E nela os olhos espantados fita / Que desejos acendem [...]” (ibíd.: 208). Sabina não o viu, continua ingenuamente se banhando, ora se descobrindo, ora se ocultando nas águas, enquanto ele observa:

Súbito erige o corpo a ingênua virgem.

[...] 
A figuração da mulher negra e a...

Para a margem caminha, tão serena,

Tão livre como quem de estranhos olhos

Não suspeita a cobiça... Véu da noite,

Se lhos cobrira, dissipara acaso

Uma história de lágrimas. (ibíd.: 209).

Vemos aqui o comentário do poeta: se Otávio não a visse, se outras circunstâncias, como a noite, impedissem que ele avistasse Sabina nua, "uma história de lágrimas" poderia ter sido evitada, quer dizer, o destino de Sabina, mesmo no estreito escopo de infelicidade que a escravidão impõe, poderia ao menos não carregar o sentido trágico da ilusão plantada e arrancada pelo filho proprietário. A ação é, desde o início, dele. Ele a vê, a deseja e, dando vazão ao seu impulso originado, frise-se, das circunstâncias, e não de um sentimento anterior - se descobre para ela:

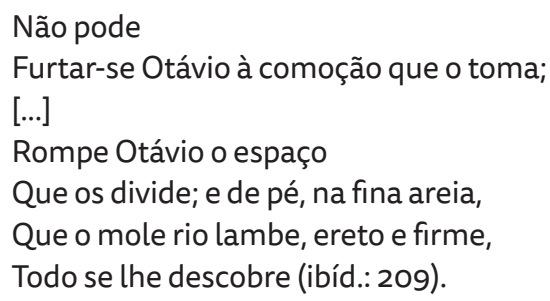

Sabina, supondo-se sozinha, de repente o vê. 0 poeta narra assim a sua reação e os seus sentimentos nesse momento:

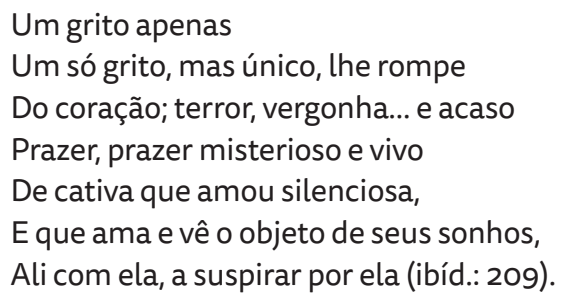

Sua primeira reação é de susto, "terror”, em princípio o medo de ser violentada; "vergonha", por estar ali nua diante de um homem. Mas logo também prazer, ao ver que o objeto do seu amor silencioso "suspira por ela". Nota-se aqui a sua ingenuidade, que, talvez julgando os sentimentos dele a partir dos seus próprios, vê amor onde existe apenas o desejo sexual. As palavras que ele na sequência lhe dirige confirmam e incrementam essa ilusão já nascida na subjetividade de Sabina:

Flor da roça nascida ao pé do rio, Otávio começou -talvez mais bela Que essas belezas cultas da cidade, Tão cobertas de joias e de sedas, Oh! não me negues teu suave aroma! Fez-te cativa o berço; a lei somente Os grilhões te lançou; no livre peito De teus senhores tens a liberdade, A melhor liberdade, o puro afeto 
Que te elegeu entre as demais cativas,

E de afagos te cobre! Flor do mato,

Mais viçosa do que essas outras flores

Nas estufas criadas e nas salas,

Rosa agreste nascida ao pé do rio,

Oh! não me negues teu suave aroma! (ibíd.: 209 y s.)

Observamos a comparação de Sabina com as moças da cidade, da sua classe social. Sabina é "flor da roça", "flor do mato", "rosa agreste", "mais viçosa" e "mais bela" que as outras belezas cobertas de adereços e roupas finas, flores criadas na estufa das salas. Nessa fala, acentua-se a diferença social de Sabina com as outras moças com quem ele convive - e lembremos que também ela gosta de roupas finas - mas, nessa comparação que visa a sedução, Sabina figura exuberante, superior. Ao lado disso, aparece a cruel categoria da "cria da casa”, a escrava quase livre, quase senhora, quase como da família. Sua condição de escrava é atribuída primeiro ao seu nascimento: decerto é filha de mãe escrava; talvez de ambos pai e mãe escravos, mas isso não é especificado no poema. Como ela é mestiça, pode bem ser filha de algum senhor ou outro frequentador da casa grande, como será seu filho. Em segundo lugar, sua condição de escrava é derivada da lei. Nascimento e lei aparecem nesse discurso como elementos externos à relação que ela de fato teria com a família proprietária e seu filho: na prática e na verdade, ela é livre, porque "no livre peito dos teus senhores", ou seja no sentimento dos seus donos, ela é objeto de um "puro afeto", que a distingue das demais escravas. Nascimento e lei que determinam a sua escravidão não são questionados, antes são naturalizados como realidades imutáveis; mas poderiam ser sobrepujados, na prática e na relação real, pelo sentimento de afeto dos proprietários.

A peculiar perversidade desse discurso de sedução está em colocá-la como livre e sua quase igual. Assim promove nela a ilusão de amor e de relacionamento humano que nesse momento deve povoar a sua imaginação e sonho, confirmados ainda pelo seu próprio sentimento de amor verdadeiro. Trata-se de um discurso que, como sabemos, será desmentido pela prática de Otávio. Mas Sabina ainda não sabe. Chorou duas lágrimas, levadas pelo rio "indiferente ao bem e ao mal que lhe povoa as margens", assim como a natureza que segue sempre seu curso "deixa ao homem / Padecer e saber que sente e morre".

Otávio suplica por seu "suave aroma”. Sabina, virgem, resiste por três dias, mas "na quarta aurora" seu pudor a abandona, e ela vive por alguns breves dias o seu sonho de amor. É interessante a imagem que o poeta desenha do pudor que se vai, "voa deleitoso". É uma imagem desprovida de moralidade, que termina com o desejo do próprio poeta de que o gozo pudesse se eternizar e "Suster a hora abençoada e curta /Da ventura que foge”. Dos dias venturosos de Sabina, o poeta escreve:

Sabina viu correr tecidos de ouro

Aqueles dias únicos na vida

Toda enlevo e paixão, sincera e ardente

Nesse primeiro amor d'alma que nasce 
E os olhos abre ao sol. Tu the dormias, Consciência; razão, tu lhe fechavas

A vista interior; e ela seguia

Ao sabor dessas horas mal furtadas

Ao cativeiro e à solidão, sem vê-lo

O fundo abismo tenebroso e largo

Que a separa do eleito de seus sonhos,

Nem pressentir a brevidade e a morte! (ibíd.: 210 y s.)

Sabina vive o "primeiro amor d'alma que nasce e os olhos abre ao sol". Não uma vocação sensual, não um desejo sexual inconsequente e livre das amarras do casamento - como será para Otávio. Envolvida pelos sentimentos de sua alma, Sabina deixa dormir a consciência e a razão, e fica inconsciente do fundo abismo tenebroso e largo que a separa de Otávio, a escravidão. As horas que passa com ele são, segundo nosso poeta, "mal furtadas ao cativeiro e à solidão", que constituem e definem o todo verdadeiro e prático de sua vida. No seu envolvimento, não está ciente de que essas horas serão breves, nem pressente sua própria morte.

Terminado o período de férias de Otávio, ele parte para a cidade e Sabina fica, grávida:

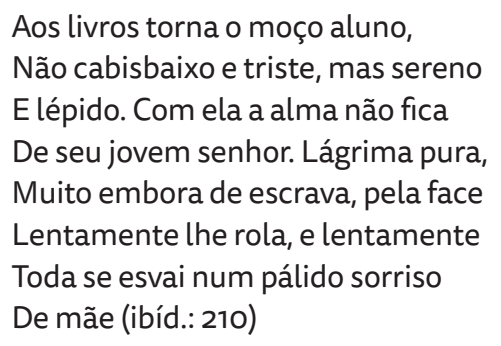

Aos livros torna o moço aluno, Não cabisbaixo e triste, mas sereno E lépido. Com ela a alma não fica De seu jovem senhor. Lágrima pura, Muito embora de escrava, pela face Lentamente the rola, e lentamente Toda se esvai num pálido sorriso De mãe (ibíd.: 210)

Ora, Otávio parte leve, seu coração não o prende a Sabina. Fica evidente o cinismo de suas palavras sedutoras: em nenhum momento ele cogitou um relacionamento de amor, sempre e apenas uma satisfação sexual; em nenhum momento as suas palavras de liberdade e igualdade, fundadas no afeto de seus "senhores" foram verdadeiramente sentidas. Já Sabina verteu uma "Lágrima pura / Muito embora de escrava": é dela o sentimento puro, que contradiz seu status social subumano.

Podemos observar a subversão do estereótipo da mulata fornicaria: Sabina é o núcleo humano da relação, é dela a alma delicada, os sentimentos sinceros. Entretanto, ela é colocada pela ação e pelo desejo sedutoramente imposto do "senhor moço" na condição de corpo desfrutável e livre das amarras da moralidade. É dele esse desejo, e não dela: ela não está absolutamente confortável nessa condição imposta, que contraria sua subjetividade amorosa e sonhadora. Também pela sua gravidez vemos subverter-se o estereótipo racista da infertilidade: Sabina engravida na primeira e única relação de amor que vive.

Partindo Otávio, o poeta narra os efeitos da aventura de Sabina na sociedade da fazenda. "Uma invejosa" que lhe atribui ares de senhora, um pajem apaixonado faz planos de vingança, um ancião conta histórias de escravas "amadas e 
orgulhosas / Castigadas do céu por seus pecados, / Mortas entre os grilhões do cativeiro". Nota-se que da casa grande nada se ouve dizer. A situação de Sabina grávida do filho do dono não causa nenhum tipo de escândalo, reação ou comentário entre os proprietários, apenas entre os trabalhadores Sabina é objeto da falação. Salienta-se também que ela não se afeta: "Assim falavam / Os cativos do engenho; e porventura / Sabina o soube e o perdoou” (ibíd.: 211 y s.).

Seus sentimentos nesse período se resumem à saudade, suprida em parte pela emoção da maternidade: "Sabina é mãe; o sangue livre / Gira e palpita no cativo seio / E lhe paga de sobra as dores cruas / Da longa ausência” (ibíd.: 206). Após as saudades, vem a esperança. Num único verso, o poeta caracteriza a ilusão de Sabina de que o retorno de Otávio o traria de volta a ela.

Mas, como já vem sendo tramado no poema, Otávio se apaixona e se torna noivo de uma moça que conheceu em um serão no Rio de Janeiro. É notável a diferença de paixão: Sabina é seduzida para a relação sexual; a moça da cidade, de "cabelos castanhos", se faz noiva, é para casar - vemos realizado aqui o ditado de que partimos neste texto, agora desvendado em suas bases sociais e no caráter do proprietário. 0 poeta, nessa passagem, atribui o desfecho à volubilidade do coração de Otávio, por sua vez advinda da "fortuna adversa": "Ora, quis fortuna adversa / Que o coração do moço, tão volúvel / Como a brisa que passa ou como as ondas [...]" (ibíd.: 212). Aqui encontramos um traço de ironia por parte do eu-lírico, uma vez que deixara antes explícito que Otávio partira sereno e lépido, e seu coração não ficara com Sabina; bem como deixara expresso o abismo tenebroso e largo que a separava dele. Ora, não se trata de volubilidade ou de acaso. Antes, os elementos do poema são suficientes para determinar que tanto o destino dele, casar-se com uma moça branca de sua classe, como o dela, dar à luz mais um bastardo da casa grande, mestiço e escravizado, como também ela mesma talvez o seja - são necessidades sociais. 0 mau-caratismo de Otávio encontra-se no fato de que, como em Cândido Neves, não há conflito interno. A desumanidade social está impressa serenamente em seu caráter. Ele é alheio e insensível aos sentimentos de Sabina, ela é, para ele e para todo o efeito social, ao contrário de suas palavras forjadas para a sedução sexual, uma escrava.

Otávio volta conduzindo a esposa, para a festa "longa e ruidosa" que o pai lhes preparara. Sabina os vê chegar "atônita e pasmada", e nesse instante breve decide matar-se e ao filho que carrega, naquele mesmo rio:

Morrerá comigo.

O fruto de meu seio; a luz da terra

Seus olhos não verão; nem ar da vida

Há de aspirar... (ibíd.: 212)

O amor materno impede seu gesto. 0 desfecho do poema é particularmente trágico, porque não a condena à morte, mas sim a sofrer silenciosamente a ausência integral de possibilidade de amor e de sonho, na dura consciência de que, malgrado cria da casa e eleita entre as cativas, é e será escrava. 


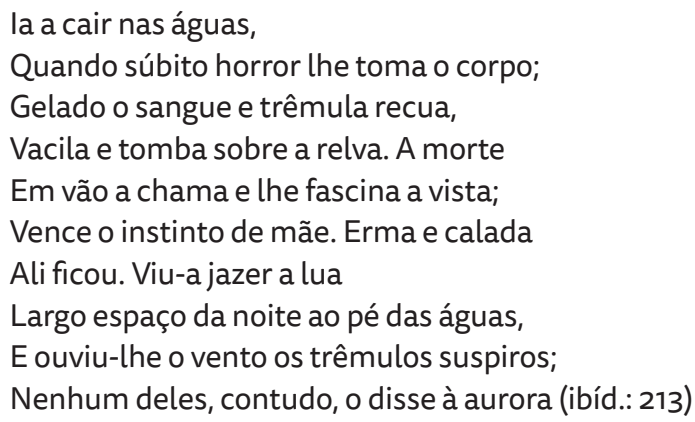

O último verso traz essa noção do silenciamento e perenidade dos seus sofrimentos. Suspirou e foi ouvida pelos ventos, vista pela lua e pelas águas, mas nenhum contou à aurora: no dia seguinte, a vida seguiu como dantes, e como sempre será.

Poderíamos questionar a ingenuidade de Sabina ao sonhar e supor algum outro destino que não este. Contudo, no poema, essa ingenuidade de justifica pela perversa falsidade da condição de mucama, escrava quase senhora, bem como pela sedução, neste mesmo sentido, de Otávio. É o que, na minha visão, este poema denuncia, quase como uma tese. Acrescenta-se a isso a peculiar delicadeza de seus sentimentos, que torna seu destino ainda mais insuportável e trágico. Sabina pertence, assim, ao rol das mulheres que exibem em sua subjetividade uma humanidade tolhida pela escravidão, aqui desenhados no amor d'alma de mulher e de mãe, a partir da qual se desvendam os demais caracteres e todo o conjunto das relação sociais em que se insere.

\subsection{Mariana}

Mariana é uma personagem similar a Sabina em dois elementos centrais: a sua condição de mestiça bela e "cria da casa"; e sua paixão principal, motor da história, o amor pelo filho proprietário. Difere, contudo, em alguns aspectos relevantes: vive em ambiente urbano, no Rio de Janeiro, e não carrega a mesma ingenuidade que vimos na personalidade de Sabina. Além disso, a construção da sua história é distinta, primeiro, por dar-se sob a forma de um conto narrado em primeira pessoa, com dois narradores, o que faz com que o nosso olhar se volte para o interior dos narradores, em especial daquele que conta a sua história com Mariana; segundo, pela ação mesma, em que o seu amor não é realizado, e por seu destino, o suicídio efetivamente consumado. Em síntese, sua história consiste na paixão pelo senhor-moço e a perspectiva do casamento deste com uma prima, que motiva duas fugas. Na primeira, é trazida de volta por ele, na segunda, recusa-se a retornar e comete suicídio.

O conto "Mariana"10 tem início com o encontro de quatro amigos que fazem parte da sociedade de Coutinho, o filho da família proprietária de Mariana e objeto de sua paixão. $O$ encontro se dá pela ocasião da volta de Macedo, primeiro narrador da história, ao Rio de Janeiro, depois de passar quinze anos viajando pela Europa e Oriente Médio. Quatro amigos se encontram. Este Macedo, cuja riqueza, advinda provavelmente do rentismo, e ociosidade são atestadas no fato de que esteve 
nos últimos quinze anos literalmente de passagem pela vida: “Não há decepções possíveis para um viajante, que apenas vê de passagem o lado belo da natureza humana e não ganha tempo de conhecer-lhe o lado feio" (Machado de Assis, 2008c: 1). Coutinho, também herdeiro e rentista, "não hesitou em dizer que era mais ou menos o que era outrora a respeito da ociosidade" (ref.). Os outros dois são, um proprietário de uma "grande casa comercial", casado com uma filha no colégio, e um escrivão de uma vara cível. Sobre eles, Macedo diz:

O negociante não hesitou em dizer tudo quanto sofrera antes de alcançar a posição atual. [...] $O$ escrivão achou-se um tanto envergonhado quando the tocou a vez de dizer a sua vida; todos nós tivemos a delicadeza de não insistir nesse ponto. (ibíd.: 1 y s.)

Trata-se, portanto, de quatro amigos da elite proprietária do Rio de Janeiro, da segunda metade do século XIX, o que se mostra pela efervescência comercial da cidade, que o viajante observa. Os dois primeiros, os únicos nomeados, Macedo e Coutinho, são herdeiros e bon-vivants. O negociante, pertencente ao mesmo estrato, construiu uma vida de capitalista e homem casado. 0 escrivão é um que, para sua vergonha, não alcançou uma posição elevada, mas vive uma vida remediada a partir do seu posto de trabalho. Nota-se que o fato de jamais terem feito nada na vida não é motivo de embaraço para Coutinho e Macedo, uma vez que são ricos; ao contrário, não ser rico é motivo de vergonha para o escrivão.

A conversa começa pela narração das viagens de Macedo, o relato das dificuldades do negociante para alcançar a sua posição e logo passa para vida de Coutinho. Na forma de diálogo entre eles, ficamos sabendo que o seu casamento com a prima Amélia, então sua noiva, não se realizou, e que ela agora era casada e fazendeira. Ao perguntarem o motivo pelo qual o casamento não se deu, Coutinho responde que "Não foi possível". Essa conversa o deixa sério, e ele resolve então fazer uma confidência, contar algo que guardou consigo pelos últimos quinze anos:

-Eu namorava a prima Amélia, como sabem; o nosso casamento devia efetuar-se um ano depois que daqui saíste. Não se efetuou por circunstâncias que ocorreram depois, e com grande mágoa minha, pois gostava dela. Antes e depois amei e fui amado muitas vezes; mas nem depois nem antes, e por nenhuma mulher fui amado jamais como fui...

-Por tua prima? perguntei eu.

-Não; por uma cria de casa (ibíd.: 3).

É interessante observar aqui que a história de Mariana, esta “cria da casa”, começa com uma particularidade, a de ser rememorada a partir da conversa sobre o casamento não realizado. Coutinho diz aqui que o casamento "não se efetuou por circunstâncias que ocorreram depois”, e passa a contar a história do amor de Mariana como se não houvesse conexão entre as duas coisas. Na verdade, saberemos, o casamento não se efetivou precisamente por causa dessa história. Aqui já se entrevê a recusa de Coutinho em admitir a relevância que esse amor teve para ele mesmo e para a sua vida. 
Macedo comenta ainda o espanto de todos, que desconhecem a história, a absorção de Coutinho nas memórias evocadas, mas, partir desse momento do conto, a narração passa para a voz de Coutinho, que seguirá até o final. Apenas no último parágrafo, em que voltamos do passado para o presente encontro entre os amigos, a voz narrativa é retomada por Macedo. Nossa heroína é então apresentada:

-Chamava-se Mariana, continuou ele alguns minutos depois, e era uma gentil mulatinha nascida e criada como filha da casa, e recebendo de minha mãe os mesmos afagos que ela dispensava às outras filhas. Não se sentava à mesa, nem vinha à sala em ocasião de visitas, eis a diferença; no mais era como se fosse pessoa livre, e até minhas irmãs tinham certa afeição fraternal. Mariana possuía a inteligência da sua situação, e não abusava dos cuidados com que era tratada. Compreendia bem que na situação em que se achava só lhe restava pagar com muito reconhecimento a bondade de sua senhora (ibíd.: 3).

Novamente, temos diante de nós a situação perversa da "escrava quase senhora”, aqui expressa com todo o cinismo do proprietário. Esse cinismo se verifica no modo como o proprietário expõe a condição concreta de Mariana justificando-a como positiva, ocultando sua contradição intrínseca e encontrando como motor dessa condição supostamente favorável a "bondade de sua senhora". Ao mesmo tempo em que afirma que Mariana recebia "de minha mãe os mesmos afagos que ela dispensava às outras filhas", era "como se fosse pessoa livre" e até as suas irmãs lhe tinham certa afeição fraternal, expõe, como se não se tratasse de contradição, que ela "Não se sentava à mesa, nem vinha à sala em ocasião de visitas" e que tinha ciência de sua situação, quer dizer, do seu privilégio com relação às demais escravas, do qual "não abusava" e sabia que tinha de "pagar com muito reconhecimento". Ou seja, expressa positivamente a sua condição, mas oferece os elementos para que a positividade e privilégio advogados em seu discurso sejam desvendados por nós como relativos e, principalmente, como elementos que não alteram a condição de escrava, mantida tal e qual em sua essência.

Nota-se nessa passagem que a figura da mãe aparece imediatamente quando o assunto passa a ser Mariana. Enquanto de Mariana enuncia apenas que se trata de "uma gentil mulatinha", cria da casa e ciente de sua condição privilegiada, da mãe ele destaca os afagos e a bondade. A mãe permeará toda a história, servindo muitas vezes de justificativa de suas ações, e reputada sempre como o extremo da bondade e da sensibilidade. Entretanto, o narrador expõe a cada passo o terror que essa "sua senhora" inspira em Mariana, indicando por essas reações o poder que tem sobre ela e, inferimos, a sua capacidade de castigar e ser perversa. Pelos elementos que o conto traz, é possível aproximar em um aspecto a relação de mãe e filho configurada aqui com aquela entre Bento Santiago e Dona Glória. Em particular, a santificação da mãe proprietária pelo filho herdeiro, a generosidade e os sentimentos atribuídos por ele como motor de todas as ações dela, distorcendo seu real significado, buscando ocultar sua dimensão de interesse, egoísmo ou crueldade. Adiante, retornaremos a esse ponto. Sigamos a caracterização que o narrador nos dá de Mariana: 
A sua educação não fora tão completa como a de minhas irmãs; contudo, Mariana sabia mais do que outras mulheres em igual caso. Além dos trabalhos de agulha que the foram ensinados com extremo zelo, aprendera a ler e escrever. Quando chegou aos 15 anos teve desejo de saber francês, e minha irmã mais moça lho ensinou com tanta paciência e felicidade, que Mariana em pouco tempo ficou sabendo tanto como ela.

Como tinha inteligência natural, todas estas coisas lhe foram fáceis (ibíd.: 3).

Mariana aprendeu facilmente tudo o que lhe foi ensinado: costura, leitura e escrita e língua francesa, porque tinha "inteligência natural". Observamos que, além de aprender com facilidade, parte dela o interesse de conhecer francês, o que não participava da educação em princípio oferecida. $O$ narrador ainda dá a entender, pelo uso da voz passiva, que ela aprendeu por conta própria a leitura e a escrita. Mas, notamos que a ênfase ativa é novamente dada à família: "lhe foram ensinados com extremo zelo", e "minha irmã mais moça lho ensinou com tanta paciência e felicidade” - embora não deixe de expressar a inteligência de Mariana, mais méritos são atribuídos às irmãs, à sua família. Esse trecho confirma ainda o sentido cínico que procuramos descobrir na passagem anterior. Mariana não recebeu educação tão completa como as irmãs, mas "sabia mais do que outras mulheres em igual caso”. Ou seja, ela está sempre alçada em situação de privilégio com relação às outras escravas. Em nenhum momento se olha pelo viés do seu prejuízo com relação às mulheres efetivamente livres. Assim se constrói a naturalização da sua condição de escrava, pela qual se medem todos os seus supostos privilégios de "cria da casa". Coutinho continua:

O desenvolvimento do seu espírito não prejudicava o desenvolvimento de seus encantos. Mariana aos 18 anos era o tipo mais completo da sua raça. Sentia-se-lhe o fogo através da tez morena do rosto, fogo inquieto e vivaz que lhe rompia dos olhos negros e rasgados. Tinha os cabelos naturalmente encaracolados e curtos. Talhe esbelto e elegante, colo voluptuoso, pé pequeno e mãos de senhora. É impossível que eu esteja a idealizar esta criatura que no entanto me desapareceu dos olhos; mas não estarei muito longe da verdade (ibíd.: 3)

Aqui temos a sua descrição física. Sua beleza é ressaltada a partir de uma afirmação que a distingue das mulheres brancas e a compara às demais mulheres negras: éo tipo mais completo da sua raça. Feita essa ressalva, sua beleza aparece tão radiante a Coutinho e a nós que ele cogita a possibilidade de a estar idealizando a partir de uma memória antiga. Tanto é que chamava a atenção das pessoas que frequentavam a casa e em particular do seu tio: "Mariana era apreciada por todos quantos iam a nossa casa, homens e senhoras. Meu tio, João Luís, dizia-me muitas vezes: -'Por que diabo está tua mãe guardando aqui em casa esta flor peregrina? A rapariga precisa de tomar ar"' (ibíd.:3). Vemos uma expressão do interesse que Mariana despertava, aqui implicitamente sexual. Chama a atenção também o termo "flor peregrina”, quer dizer, flor vinda de outras paragens. À frente, na ocasião da primeira fuga de Mariana, este mesmo tio retorna à narração para o seguinte diálogo:

O tio João Luís disse-me em particular que eu fora um asno e um ingrato.

-Por quê? perguntei-lhe. 
-Porque devias ter posto Mariana debaixo da minha proteção, a fim de livrá-la do mau tratamento que vai ter.

-Ah! não, minha mãe já lhe perdoou.

-Nunca lhe perdoará como eu (ibíd.: 9).

Essa conversa confirma o sentido do interesse que tinha o tio em Mariana, levá-la para sua casa e tomá-la como amante. Notamos o uso do termo ingrato: o sobrinho teria sido ingrato por não lhe proporcionar a possibilidade de levar Mariana consigo, para pudesse perdoá-la como ninguém. Mariana encarna, na imaginação do tio, a mulata fornicaria, tipo avesso e oposto ao seu caráter, como a ação do conto demonstra.

Outro ponto fundamental aqui é a perspectiva de maus tratos que Mariana receberia da mãe de Coutinho pela fuga. Este afirma que a mãe já perdoou, mas ficamos com essa ameaça, a arbitrariedade desse perdão e mais uma vez a reafirmação da condição de escrava de Mariana. Voltando ao ponto em que estávamos, à exortação inicial do tio de que a "flor peregrina" precisava tomar ar, ou seja, sair de casa, Coutinho oferece o seguinte comentário:

\begin{abstract}
Posso dizer, agora que já passou muito tempo, esta preocupação do tio nunca me passou pela cabeça; acostumado a ver Mariana bem tratada parecia-me ver nela uma pessoa da família, e além disso, ser-me-ia doloroso contribuir para causar tristeza a minha mãe. (ibíd.: 4)
\end{abstract}

Novamente, vemos figurar a mãe. Essa mãe, que a narrativa deixa entrever como pessoa capaz de maus-tratos e que inspira pavor em Mariana, é na boca do filho alguém a ser protegida da tristeza que lhe causaria a ausência de Mariana. Duas coisas ocultam-se nesse discurso: um possível desejo de Coutinho, inconsciente e inconfessável para si próprio, de ter Mariana perto de si, disfarçado em costume de vê-la em casa "bem-tratada" como "pessoa da família"; e, por certo, o interesse da mãe em manter a propriedade da escrava Mariana, dissimulado em afeto de pessoa sensível, e sempre alçada pelo filho a uma posição de benevolência.

Quando Coutinho narra brevemente o seu namoro com a prima Amélia e o arranjo do casamento, consentido pelas duas famílias, Mariana está "emprestada" a uma parenta, para costurar vestidos. Comenta neste ponto que ela era "excelente costureira". O comentário se faz en passant, mas a nós, leitores, mostra o seu valor como trabalhadora escravizada. De modo que aquela suposta "tristeza" tem aqui o seu verdadeiro conteúdo: podemos adaptar aqui os termos do cínico narrador de "Pai contra mãe", e dizer que "dinheiro também entristece".

Com o seu retorno da casa da parenta, Mariana fica sabendo dos arranjos do casamento e acaba por manifestar para Coutinho a sua tristeza, embora não revele a ele o motivo. Arranja uma desculpa, a devolução de uns charutos, para estar diante dele, e ele observa que seus olhos estão rasos de lágrimas: 
Admirou-me essa manifestação inesperada da parte de uma rapariga que todos estavam acostumados a ver alegre e descuidosa da vida. Supus que houvesse cometido alguma falta e recorresse a mim para protegê-la junto de minha mãe. Nesse caso a falta devia ser grande, porque minha mãe era a bondade em pessoa, e tudo perdoava às suas amadas crias.

-Que tens, Mariana? perguntei.

E como ela não respondesse e continuasse a olhar para mim, chamei em voz alta por minha mãe. Mariana apressou-se a tapar-me a boca, e esquivando-se às minhas mãos fugiu pelo corredor fora (ibíd.: 4 y s.).

Essa passagem traz novamente a condição de Mariana na casa. Diante de sua tristeza e aparente preocupação, ele supõe uma "falta grande" e que procurava a sua proteção para salvá-la dos castigos da mãe. Mais uma vez, reputa à mãe bondade e perdão e, ainda assim, ao ameaçar chamá-la, expõe o medo de Mariana, que lhe tapa a boca e foge pelo corredor. Em cada passo da história observamos essa mesma contradição entre o que Coutinho diz da sua condição "quase livre, quase senhora" e a sua reação, que nos mostra a real situação de escrava, sujeita a castigos e à falta de domínio sobre sua própria vida. Recordemos ainda que, sendo cria da casa, assim como Sabina e até mais, por ser uma casa urbana, Mariana não tem outra família, outros laços afetivos.

A tristeza de Mariana começa a ser objeto de conversas na família. Coutinho e sua irmã, Josefa, tratam do tema, ele supondo ainda alguma falta, e a irmã suspeitando de "algum namoro". Neste momento, Coutinho interpõe: “E quem será o namorado da senhora Mariana, perguntei rindo. O copeiro ou o cocheiro?" O tom de galhofa é constante, bem como a reiteração de sua condição de classe. A resposta de Josefa é romântica e inadvertida: "Tanto não sei eu; mas seja quem for, será alguém que lhe inspirasse amor; é quanto basta para que se mereçam um ao outro" (Machado de Assis, 2008c: 5). Essa resposta carrega uma ironia para nós e para os ouvintes de Coutinho, uma vez que já sabemos que a paixão de Mariana é dirigida a ele. Para a família, qualquer pessoa que inspirasse amor a Mariana seria digno dela, contanto que pertencente à mesma classe. A ressalva não se faz explicitamente, mas está subjacente na naturalização da impossibilidade de a escrava amar um senhor. Essa impossibilidade confirma mais uma vez o viés senhorial dos privilégios de Mariana: sempre medidos pela condição das demais escravas, nunca pela condição das mulheres livres. $O$ amor da escrava pelo senhor é por este compreendido como um atrevimento. Quando a irmã Josefa comunica a Coutinho a sua desconfiança de que ela ama a ele, sua resposta é: "Que seja eu o querido de Mariana? perguntei-lhe com um riso de mofa e incredulidade. Estás louca, Josefa. Pois ela atrever-se-ia!.... E a irmã comenta, “Parece que se atreveu” (ibíd.: 7).

Contudo, antes dessa revelação, tratada por ele, mais uma vez, com galhofa, Coutinho sentiu, pelos modos como Mariana falava e se comportava, que o seu sentimento era elevado e nobre, o que lhe pareceu contrário à condição de escrava. Ele afirma: "Parecia-me evidente que ela sentia alguma coisa por alguém, e ao mesmo tempo que o sentia, certa elevação e nobreza. Tais sentimentos contrastavam com a fatalidade da sua condição social" (ibíd.: 6). 
Vemos aqui a fetichização operada por Coutinho: a condição da escravidão impede que sentimentos elevados e nobres sejam efetivamente realizados, bem como outras atividades e modos de vida que incluíssem o conhecimento, artes, viagens etc. Mas essa impossibilidade não é subjetiva, própria da pessoa escravizada. Ao contrário, como todo o conto mostra, o obstáculo é imposto e exterior às capacidades subjetivas. 0 escopo de vida sob a escravidão é extremamente restrito, e isso pode levar a pessoa escravizada a não desenvolver potencialidades que existem nela como suas. Em outros casos, essas potencialidades podem se desenvolver parcialmente ou integralmente. Neste conto, Machado explora essa questão. Mariana, pela condição diversa das demais escravas, pôde aprender a ler e a escrever, e a falar francês, além da costura. Sabe-se lá que outros conhecimentos e sensibilidades ela pode ter desenvolvido no contato com livros, revistas e outros meios que existem apenas na casa grande - e que podem ter permanecidos ocultos aos olhos do tosco Coutinho.

Mariana é escrava, mas teve acesso a atividades que em geral eram próprias das pessoas livres, eis o privilégio a que se refere Coutinho. A peculiaridade da posição com a qual tem acesso a essa cultura lhe confere habilidades subjetivas também peculiares. Uma vez que esses conhecimentos, capacidades e sensibilidades não alteram em nada a restrição da sua vida, que permanece propriedade alheia, tal privilégio lhe parece antes um prejuízo:

-Não falemos nisso, nhonhô. Não se trata de amores, que eu não posso ter amores. Sou uma simples escrava.

-Escrava, é verdade, mas escrava quase senhora. És tratada aqui como filha da casa. Esqueces esses benefícios?

-Não os esqueço; mas tenho grande pena em havê-los recebido.

-Que dizes, insolente?

-Insolente? disse Mariana com altivez. Perdão! continuou ela voltando à sua humildade natural e ajoelhando-se a meus pés; perdão, se disse aquilo; não foi por querer: eu sei o que sou; mas se nhonhô soubesse a razão estou certa que me perdoaria (ibíd.: 5 y s.)

Mariana é, sem dúvida, a personagem do conto mais consciente da contradição que vive. Diferentemente de Sabina, que chega a acreditar na própria ilusão, auxiliada pelas ações de Otávio que concorrem para alimentá-la, Mariana não cria nem nutre qualquer tipo de fantasia. Tem claro para si que, como uma "simples escrava", não pode ter amores. Sabe bem que teve "benefícios" se compara sua vida com as das demais escravas, mas os enxerga como "uma grande pena". Ela refreia a altivez, sua primeira reação, e em seguida se ajoelha recuperando a humildade obrigatória. Tal é a peculiaridade da "cria da casa” em geral e de Mariana em particular: a janela aberta para um campo de liberdade e possibilidades, para dar com a cara na porta fechada da efetiva escravidão.

Aqui, a restrição de sua vida lhe aparece na paixão irrealizável, o amor impossível. Antes de a irmã desconfiar de sua paixão por Coutinho, Mariana é instada de vários modos a contar quem é o objeto de seu amor. A irmã emprega "todos 
os meios de sedução possíveis entre uma senhora e uma escrava", são tentados "pedidos e ameaças", como, por exemplo, "Minha mãe saberá interrogá-la”. Os meios explicitam as chantagens, o poder, e o pavor de Mariana, que estremece sempre que Coutinho menciona a mãe. Nesse contexto, a fim de que este parasse de interrogá-la, Mariana concede que gosta de uma pessoa, mas não pode dizer quem:

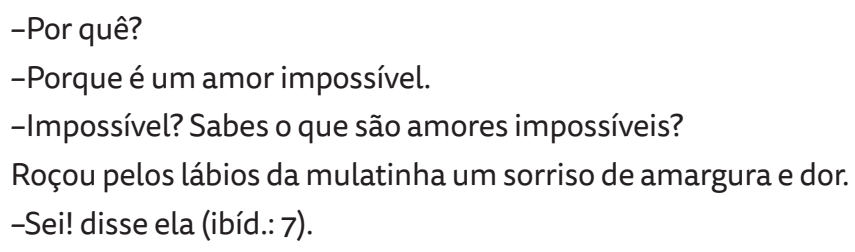

De fato, se algum amor pode ser considerado impossível nesse contexto social, é este, da escrava pelo senhor. A impossibilidade reside, evidentemente, na diferença de classe que, na condição brasileira, não é somente a diferença entre proprietário e não proprietário, como nos países de capitalismo clássico, mas entre proprietário e propriedade. Essa relação social aparece na consciência de Coutinho como uma fatalidade da natureza. Essa concepção tem um viés bastante cínico, já que a perpetuação dessa condição lhe favorece e interessa. Vale notar que essa relação social encontra um contraponto, no período em que a história se passa, na forma de exploração europeia; ali, embora numa mescla de relações semi-feudais no campo, bem como da mesma escravidão moderna em certos setores - a depender das localidades - o fato é que já se vislumbra a universalização do assalariamento, a expansão industrial e, mesmo, no preciso período em que vive Mariana, a Europa assiste ao primeiro movimento das lutas proletárias, à primeira tomada de consciência da sua peculiaridade de classe e perspectiva de superação do modo capitalista de produção. Coutinho, narrando o acontecimento quinze anos depois, pertencendo à classe proprietária com acesso aos conhecimentos e à Europa - a conversa se dá precisamente pela ocasião do retorno do amigo Macedo depois de quinze anos passados ou passeados no velho continente - não tem nenhum rasto do pensamento liberal de sua época, sequer na aparência, sequer nos termos emprestados: está perfeitamente acomodado na naturalização da escravidão, cuja causa está no nascimento. Nem dele nem de seus amigos extraímos alguma ponderação nesse sentido.

Ao contrário, todo sentimento que possa parecer mais intenso e humano do que o que se poderia ter por uma escrava é cuidadosamente oculto sob outros interesses e impulsos - destaca-se nestes a preocupação com a mãe. Ademais, a descoberta do seu amor o leva a considerar a possibilidade de ter com ela uma relação sexual inconsequente, como seria aceito pela sociedade. Vejamos como isso aparece. Algumas semanas antes do casamento de Coutinho, Mariana adoeceu. Diante de sua recusa a tratar-se e alimentar-se, que levava a recear sua morte; vendo que a "mãe estava louca de pena" e as "irmãs sentiam deveras a doença da escrava", Coutinho resolveu "fazer um ato de caridade": 
Fui ter com Mariana e lhe pedi que vivesse.

-Manda-me viver? perguntou ela.

-Sim (ibíd.: 7).

Mariana de fato se restabelece e retoma inclusive a alegria, que o narrador não sabe explicar e a irmã Josefa atribui ao plano da sua ação seguinte, a primeira fuga. É de se supor que aqui Mariana concebe a ideia dos suicídio, talvez justamente diante da ordem recebida de viver. Vale referir a confissão que o narrador nos faz e aos seus amigos ao contar a doença e restauração da nossa heroína:

Confesso, entretanto que, apesar de não competir de modo nenhum os sentimentos de Mariana, entrei a olhar para ela com outros olhos. A rapariga tornara-se interessante para mim, e qualquer que seja a condição de uma mulher, há sempre dentro de nós um fundo de vaidade que se lisonjeia com a afeição que ela nos vote (ibíd.: 8).

Explicita seu interesse e o justifica por uma vaidade. É claramente para ele mais fácil expor a sua vaidade do que um sentimento por uma escrava. Também para ele é fácil confessar que pensara em usá-la sexualmente: "Além disto, surgiu em meu espírito uma ideia que a razão pode condenar, mas que nossos costumes aceitam perfeitamente" (ibíd.: 8). Notamos assim o que ele pode falar com relação ao seu interesse por Mariana: os supostos sentimentos da mãe e das irmãs, sua vaidade e a lisonja por ter uma mulher interessada em si, e o seu impulso sexual. Contudo, a reação de Amélia ao seu interesse pela escrava nos mostra que foi bem mais intenso do que ele faz parecer. Como referimos, é precisamente esta a causa do rompimento do seu noivado, de que trataremos adiante.

A primeira fuga de Mariana se dá poucos dias antes do casamento. A primeira reação de Coutinho, ao ver a mãe "triste e indignada", a quem "doía a ingratidão da escrava", é propor que ela seja capturada e "colocada na situação verdadeira do cativeiro". E completa: "Disse isto por me estar a doer o desespero de minha mãe. A verdade é que, por simples egoísmo, eu desculpava o ato da rapariga." 0 desespero da mãe, frise-se, amainava-se com a perspectiva do "cativeiro", a vida na senzala.

Passado o dia em diligências para capturá-la, inclusive recorrendo à polícia, e após considerar a possibilidade de suicídio, porque conhecia a razão dela, Coutinho a encontra à noite na esquina da casa de Amélia. Encontra-a triste, e ela mesma lhe diz, ao perguntar por que fugira, que sofria muito. Após uma conversa em que Coutinho a acusou de ingrata, de já supor-se "senhora e livre", ameaçar levá-la à força por soldados e por fim prometer que a protegeria da mãe, Mariana resolve-se por retornar, dizendo-se "disposta a tudo". Aqui ela apresenta uma completa ausência de perspectivas, não se importando inclusive com os castigos que viesse a receber, e dando mostras de ter desistido da vida.

Já diante da resolução de retornar, dá-se o seguinte diálogo, que mostra toda a covardia de Coutinho e toda a coragem de Mariana, que, pela primeira vez, 
explicita francamente o seu amor pelo senhor-moço. Ele pergunta, para a indignação dela, se alguém a seduziu para fugir, pretendendo ocultar que estava ciente do amor dela por ele:

-Se alguém me seduziu? perguntou ela; não, ninguém; fugi porque eu o amo, e não posso ser amada, eu sou uma infeliz escrava. Aqui está por que eu fugi. Podemos ir; já disse tudo. Estou pronta a carregar com as consequências disto. (ibíd.: 9)

Ao voltar, novamente o vemos contradizer-se com relação à mãe. Afirma que, ao ver Mariana, o seu prazer foi maior que a sua indignação. Entretanto, ela "Começou por invectivá-la. Intercedi a tempo de acalmar a justa indignação de minha mãe [...]” (ibíd.: 9).

Alguns dias depois, Mariana foge novamente. Sobre a reação da família, Coutinho diz: "Desta vez houve indignação apenas. Que sentimento devia inspirar a todos a insistência dessa rapariga em fugir de uma casa onde era tratada como filha?" (ibíd.: 10). À frente, o narrador resume o sentimento geral como cólera. Decide-se mais uma vez a capturá-la, a fim de lhe aplicar “o castigo competente”. Dessa vez, as buscas prolongaram-se por dois dias, e Coutinho, que se dedicou intensamente a elas, esquecendo tudo o mais, acaba por encontrá-la por acaso em um hotel, onde parara para jantar. Mariana havia se abrigado em um dos quartos do hotel e recusara-se a comer. $\mathrm{O}$ funcionário levou Coutinho ao quarto e chamou por ela. Ao vê-lo, ela se lançou aos braços dele:

-Não venho aqui para receber-te abraços, disse eu; venho pela segunda vez buscar-te para casa, donde pela segunda vez fugiste.

A palavra fugiste escapou-me dos lábios; todavia, não lhe dei importância senão quando vi a impressão que ela produziu em Mariana. Confesso que devera ter alguma caridade mais; mas eu queria conciliar os meus sentimentos com os meus deveres, e não fazer com que a mulher se esquecesse de que era escrava (ibíd.: 11).

Tenta convencê-la a voltar, dizendo que perderia muito insistindo em fugir, ao passo que "ganharia tudo se procedesse bem". "Pouco importa, disse ela; estou disposta a tudo.”. Então ele mesmo introduz a ideia do suicídio: “A matar-te, talvez?”:

-Talvez, disse ela sorrindo melancolicamente; confesso-lhe até que a minha intenção era morrer na hora do seu casamento, a fim de que fossemos ambos felizes, -nhonhô casando-se, eu morrendo (ibíd.: 12).

Não conseguindo convencê-la pelos "meios brandos", decide "empregar o meio heroico", e sai para buscar soldados a fim de levá-la à força. Nesse meio tempo, ela toma um veneno que já guardava consigo. As últimas palavras de Mariana para Coutinho corroboram a sua intenção já planejada de morrer, bem como lançam luz ao modo como ela compreende a sua situação:

-[...] eu queria matar-me depois d'amanhã. Nhonhô apressou a minha morte, nada mais. [...] Oh! continuou ela com voz fraca; não the quero mal por isso. 
Nhonhô não tem culpa: a culpa é da natureza. Só o que eu the peço é que não me tenha raiva, e que se lembre algumas vezes de mim... (ibíd.: 13).

É notável a noção que ela tem da sua condição de escrava, que se alinha à concepção do próprio Coutinho. Referimos anteriormente que a escravidão de Mariana é pressuposta por ele como fatalidade, advinda do nascimento. Aqui, observamos que essa é uma visão compartilhada também por ela: a culpa é da natureza. Mas, enquanto ele é cínico, já que essa relação lhe favorece, a visão naturalizante de Mariana envolve um caráter trágico. Sem ter um viés de pensamento que lhe permita compreender o estatuto social e histórico de sua condição, vê nela um imperativo da natureza. Aceita-a, no pensar, como necessária e insuperável. Mas, a suposta condição natural entra em confronto com a sua sensibilidade. É-lhe insuportável, de modo que não a aceita na prática e opta pelo suicídio. Ora, que outra saída haveria para ela?

Depois de narrar a morte de Mariana, Coutinho expõe seu sentimento da seguinte maneira: "Sofri muito com este acontecimento; mas alcancei que minha mãe perdoasse à infeliz, confessando-lhe a causa da morte dela" (ibíd.: 13). De novo a mãe, e sempre a mãe, situada no cume da bondade e da razão; ela vem agora perdoar o suicídio de Mariana, que, afinal, lhe tirou uma escrava. Mas essa afirmação esconde o sentimento de Coutinho por Mariana. Como indicamos, ele não aceita absolutamente esse sentimento, que contraria a pretensa desigualdade natural entre eles. Contudo, é a reação de Amélia que nos oferece, como também referimos acima, a intensidade desse sentimento. Desde a primeira fuga de Mariana, Amélia se incomoda com a atenção que Coutinho lhe dedica.

Falei tanto em Mariana que minha prima entrou a sentir um disparatado ciúme. Protestei-lhe que era loucura e abatimento ter zelos de uma cria de casa, e que o meu interesse era simples sentimento de piedade (ibíd.: 9).

Os ciúmes de Amélia são afirmados como disparatados, por duas razões: o sentimento dele por Mariana era de "simples piedade", já que se tratava de uma "cria da casa". No seu discurso, demarca a diferença entre ele e Mariana como evidência de que um sentimento por ela seria descabido. Contudo, o fato é que falou muito - tanto - em Mariana. E sabemos que, quanto mais se fala de uma pessoa, mais interesse se demonstra por ela. Amélia, efetivamente incomodada, dirige ataques a Mariana, insistindo na família que era preciso "tratar severamente as escravas", e que era "mau exemplo mandar-lhes ensinar alguma coisa". O ciúme de Amélia a leva a usar a condição de escravidão para tentar afastar Mariana do convívio, mas não éisso que nos importa aqui. Importa que há efetivamente ciúmes e que ele advém da atitude de Coutinho. Para ele, que nunca admitiria a medida do seu interesse, Amélia foi "extremamente leviana" e "não soube conservar a necessária dignidade". Disse à prima que a situação era "absurda e ridícula" e que ela estava a "humilhar-se diante de uma escrava". Mais uma vez, a mãe aparece como contraponto positivo, embora esteja clara a sua grosseria: "Minha mãe admirou-se muito desta linguagem na boca de Amélia e redarguiu com aspereza o que lhe dava direito a sua vontade" (Machado de Assis, 2008c: 9-10), ou seja, falou o que quis como bem entendeu. 
Na ocasião da primeira fuga, após discussões e choro de Amélia, ela se acalma e subordina. Mas, na ocasião da segunda fuga, diante da atitude de Coutinho, que saiu imediatamente e não fez outra coisa até encontrar Mariana, Amélia sai da casa dele "furiosa", porque ele "estava dando maior atenção do que devia a uma escrava, embora bonita". Vemos que, no sentimento de Amélia, Mariana poderia ser uma rival, tanto pelas suas qualidades próprias, como pelas atitudes de Coutinho, que traem seus sentimentos, explicados por ele como se segue:

Confesso que naquele momento o que me preocupava mais era Mariana; não porque eu correspondesse aos seus sentimentos por mim, mas porque eu sentia sérios remorsos de ser causa de um crime. [...] Minha vaidade não era tamanha que me abafasse os sentimentos de piedade cristã. Neste estado as invectivas da minha noiva não me fizeram grande impressão, e não foi por causa delas que eu passei a noite em claro. (ibíd.: 11)

Sua preocupação maior era Mariana e foi por ela que "passou a noite em claro". Pela segunda vez, assevera aos amigos que não correspondia aos sentimentos dela. Estes seriam sentimentos cristãos de piedade. Essa é mais uma maneira de justificar a atenção dedicada a ela, além daquelas que mencionamos acima (a mãe, a família, vaidade, interesse sexual). O fato é que a atenção e o interesse dele por Mariana e em seguida o sofrimento por sua morte são a causa única do rompimento do noivado:

Amélia nada soube, mas nem por isso deixou o fato de influir em seu espírito. $O$ interesse com que eu procurei a rapariga, e a dor que a sua morte me causou, transtornaram a tal ponto os sentimentos da minha noiva, que ela rompeu o casamento dizendo ao pai que havia mudado de resolução (ibíd.: 13).

Passados quinze anos, Coutinho não se casou. Como dissemos no início, ao ser perguntado sobre o casamento com a prima Amélia, conta a história do amor de Mariana, e agora deixa claro que foi esse o motivo de não ter-se casado, embora não expresse essa conexão com toda a franqueza, dizendo apenas que "o fato" "influiu no seu espírito" e "transtornou seus sentimentos". Na minha visão, ele sente por Mariana um amor que oculta de si mesmo, porque não pode aceitar um sentimento por uma escrava. E penso mesmo que esse amor influiu no espírito dele de modo a não estreitar relações com outra pessoa. Nenhuma outra mulher é mencionada, nem antiga nem presente, embora existam em sua vida e cujos sentimentos ele compara ao de Mariana, para concluir sua narrativa:

Tal foi, meus amigos, este incidente da minha vida. Creio que posso dizer ainda hoje que todas as mulheres de quem tenho sido amado, nenhuma me amou mais do que aquela. Sem alimentar-se de nenhuma esperança, entregou-se alegremente ao fogo do martírio; amor obscuro, silencioso, desesperado, inspirando o riso ou a indignação, mas no fundo, amor imenso e profundo, sincero e inalterável (ibíd.: 13). 
Eis o amor dela, tal como reconhecido por ele. Não "uma simples exaltação de sentidos", a sua primeira hipótese de sentimento adequado a uma escrava, mas sim amor verdadeiro e profundo. Mariana não se entregou "alegremente ao fogo do martírio", e sim se encontrou numa encruzilhada trágica, em que morrer é morrer, mas viver não é viver.

Coutinho viveu a mesma vida ociosa e de relações superficiais e, quinze anos depois, é do caso de Mariana que ele se lembra de contar aos amigos, em meio a conversas gerais, quando se aventa o tema do casamento. Nada disso, entretanto, resultou em reflexão ou mudança de caráter por parte dele, que é sempre o mesmo. Na sua consciência, como para os amigos, trata-se de uma história triste, uma fatalidade sem relação com os rumos de sua vida. Por isso saem todos logo depois, "examinando os pés das damas que desciam dos carros", como nos informa Macedo restituído à posição de narrador. "Duas horas de conversa tinha-nos restituído a mocidade", conclui.

Machado opera com esse conto um desvendamento da posição e da consciência de Coutinho em especial, mas também dos amigos e da família dele. Ao pressuporem a naturalidade da escravidão, que lhes favorece, atribuem à pessoa escravizada uma menor humanidade, uma menor capacidade de sentimentos, menos necessidades propriamente humanas etc., o que os critérios de privilégio e prejuízo mais que tudo aqui evidenciam. Mas, na ação, explicita-se que o caráter e os sentimentos verdadeiros, a inteligência e a sensibilidade fina são da escrava. O narrador nos mostra isso, mas em geral não o afirma; e, quando afirma, como no caso da conclusão sobre o amor de Mariana, não tira desse reconhecimento as suas consequências necessárias. Por outro lado, sobre si mesmo e sobre a mãe, o discurso de Coutinho não poupa termos como bondade e piedade; contudo, a ação demonstra precisamente o oposto: toda a grosseria, a crueldade e a perversidade no conto tem como sujeitos o narrador e sua família: dele, o escárnio, a ameaça, a astúcia, a covardia; da mãe, a crueldade e a perversidade dos castigos físicos; do tio, a objetificação sexual; da irmã, a chantagem e também a ameaça; de Amélia, o afã de vê-la castigada e afastada.

A baixeza da família proprietária se desnuda pelas suas ações e pelas reações de Mariana, embora o narrador principal procure ocultá-la ou justificá-la no discurso. A elevação subjetiva de Mariana se sobressai, mesmo quando não é reconhecida no discurso, pelas suas ações. Vemos que os sentimentos superficiais e a vocação sensual atribuídos à mulata do estereótipo pertencem em verdade a Coutinho - que cogita toma-la sexualmente, avalizado pelos costumes - e ao tio (e Amélia o percebe bem); novamente, Machado desvenda o núcleo ativo do estereótipo e o seu caráter avesso à subjetividade da mestiça Mariana. Esse núcleo ativo consiste na condição de proprietário, que possibilita dispor das mulheres escravizadas: eis o seu substrato social, alheio a toda suposta natureza das mulheres.

A delicadeza de sentimentos com que o conjunto da ação figura Mariana também coloca a questão impossível de ser enunciada pelos narradores. Ora, se ela é capaz 
de sentimentos mais do que qualquer outra pessoa, se a sua natureza subjetiva se eleva acima das de pessoas livres, o que faz dela uma escrava, afinal? Não é possível respondê-la sem pôr em xeque a fatalidade da condição de senhor e de escravo. A esse determinismo natural se prende com avidez a consciência dos narradores e da família de Coutinho, e ele é desvendado em seu viés de classe e cinismo ao longo de toda narrativa.

Considero que o desvendamento dos determinismos naturais que conformam as consciências burguesas e são movidas pelos seus desejos e interesses, nos contos e no poema narrativo que buscamos examinar, constitui uma crítica literária ao naturalismo. O naturalismo do estereótipo da "mulata" é diretamente situado na concepção e intenção dos homens proprietários, tanto Otávio como Coutinho e o seu tio, e sempre exposto como absolutamente avesso ao caráter das mulheres retratadas. A aceitação e satisfação da "mulata" em seu papel de mulier fornicaria aparece em Mariana e Sabina subvertidos em sua verdade: são criações dos proprietários impostas pela força que ferem as suas subjetividades. A ausência de sensibilidade e sentimentos profundos também aparece de modo realista, como própria dos sujeitos da classe dominante. A esterilidade assume também aqui a sua verdade: mulheres escravizadas são impossibilitadas de serem mães, viverem a relação de maternidade em virtude da escravidão; não obstante, engravidam, e têm para com seus filhos, mesmo ainda não nascidos, uma relação intensa de amor. A figura estereotípica da escrava de trabalho aparece subvertida na figura de Arminda para também alcançar a sua essência: a condição imposta pela força e avessa ao seu impulso de liberdade, vida própria e maternidade.

A pequenez e inferioridade humana dos homens da alta classe, em oposição à sua elevada posição social, é descoberta a partir do significado efetivo e ativo desta posição: são eles os agentes da desumanização, e por causa disso, mostram-se eles mesmos subjetivamente tacanhos, animalizados. Ao contrário, as mulheres que a classe proprietária busca despir de humanidade para seu próprio proveito recusam a sua desumanização, e assim expõem um caráter humano elevado. Esse deslindamento se realiza pela figuração realista de mulheres mestiças escravizadas colocadas em situações extremas. $\mathrm{O}$ beco sem saída das três é o núcleo humano a partir do qual se figura toda a estrutura social do patriarcado escravista. Podemos dizer que, no caso brasileiro, até os dias de hoje, desvendar o fetichismo que envolve a imagem das mulheres negras requer e significa descobrir a perversidade essencial e profunda da nossa atual sociedade de classes. 


\section{Q Bibliografia}

" Cotrim, L. (2018). "Elementos da estética de Goethe na análise lukácsiana". En Rosa, D. S. (comp.). O realismo e sua atualidade. São Paulo: Outras Expressões.

" Duarte, E. de Assis (2007). Machado de Assis afrodescendente. Belo Horizonte: Crisálida.

" Duarte, E. de Assis (2009). "Mulheres marcadas: literatura, gênero, etnicidade". En Terra roxa e outras terras. Revista de estudos literários, vol. $17 \mathrm{~A}$.

"Fonseca, D. Gomes da (2020). Em torno da ironia: análise de Dom Casmurro, de Machado de Assis. Dissertação de Mestrado. FFLCH-USP, 2014 (disponível em: https://teses.usp.br/teses/disponiveis/8/8151/tde-04032015-191744/pt-br.php; acesso em 3/3/2020).

" Goethe, J. W. (2005). "Sobre verdade e verossimilhança das obras de arte". En Escritos sobre arte. Introdução, tradução e notas de Marco Aurélio Werle. São Paulo: Associação Editorial Humanitas/Imprensa Oficial do Estado de São Paulo.

" Lukács, G. (1965). "Narrar ou descrever?" En -, Ensaios sobre literatura. Tradução de Giseh Vianna Konder. Rio de Janeiro: Civilização Brasileira.

"Lukács, G. (1999). "O romance como epopéia burguesa". En Chasin, J. (comp.), Ensaios Ad Hominem, Tomo II - Música e Literatura. Santo André: Estudos e Edições Ad Hominem.

"Machado de Assis, J. (2008a). "Eça de Queirós: O Primo Basílio". En: O Cruzeiro (1878).

"Machado de Assis, J. (2008b), "Pai contra mãe". En Relíquias da Casa Velha (1906).

"Machado de Assis, J. (2008C), "Mariana". En Jornal das Famílias (1871).

" Machado de Assis, J. (2009), "Sabina". En Americanas (1875).

"Machado de Assis, J. (2009), A poesia completa. Organização e fixação dos textos de Rutzkaya Queiroz dos Reis. São Paulo: Edusp.

"Machado de Assis, J. (2019). Homenagem aos cem anos do falecimento de Machado de Assis. Obras Completas. São Paulo: Ministério da Educação e Cultura, 2008 (disponível em http://machado.mec.gov.br/, acesso em 10/4/2019. Textos extraídos de Obra Completa de Machado de Assis. Rio de Janeiro: Nova Aguilar.

"Schiller, F. (2004). "Sobre o uso do coro na tragédia". En: A noiva de Messina. Organização de Márcio Suzuki e Samuel Titan Jr. São Paulo: Cosac \& Naify.

"Suzuki, M. (2004). "A 'guerra ao naturalismo' - a propósito do coro na Noiva de Messina". En Schiller, F. A noiva de Messina. 